ISSN 2149-9527 (basılı / print) ISSN 2149-9101 (cevrimici / online)

\title{
Belirsizlik Hatları: Kuzey Kafkasya Sınır Bölgeleri ${ }^{*}$
}

\section{Thomas M. Barrett ${ }^{* *}$ Çev. Furkan Özkan}

"Kafkasya, doğası gereği olağanüstü dayanıklı, insan eliyle yapıımış istihkâmlarla korunaklı, çok sayıda garnizonun savunduğu muazzam bir kaleye benzetilebilir." Sıklıkla atıf yapılan bu satırlar, Kuzey Kafkasya'da yaşayan halklara boyun eğdirmek amacıyla etkili askeri güç kullanılması gerektiğini savunan A.A. Velyaminov'un 1828 tarihli hatıratında kaleme alındı. Velyaminov'a göre usta bir komutan bu kaleyi almak için "paralel hatlar kurmak, boşluklara doğru ilerlemek ve bölgeye boyun eğdirmek" zorundaydı. Tahkim edilmiş hattın dağların içlerine doğru gittikçe sokulması ve bu hattın saldırılar için üs olarak kullanılması Velyaminov'un fetih stratejisinin temelini oluşturuyordu. ${ }^{1}$

Herkesin bildiği "hat" sistemi savunma amaçlı inşa edilen kaleler, Kazak köyleri ve gözetleme kuleleri içeren sıralar olarak 18. yüzyılın ortalarında kurulmaya başlandı. Hatlar, Kazakların geceleri saklanabileceği ileri karakollar da içeriyordu. Tehdit oluşturan yerel unsurların hatta yaklaşması durumunda buraya konuşlanmış Kazaklar en yakın kuleye ya da Kazak köyüne işaret gönderebiliyordu. Daha

" "Lines of Uncertainty: The Frontiers of the North Caucasus" by Thomas M. Barrett, originally published in Slavic Review (vol. 54, no. 3, Autumn 1995): 578-601. The Slavic Review is published by the Association for Slavic, East European, and Eurasian Studies (formerly the American Association for the Advancement of Slavic Studies).

JOCAS Yazı İşleri Kurulu, Slavic Review dergisinin yayıncısı The Association for Slavic, East European, and Eurasian Studies'e bu makalenin Türkçe'ye çevrilerek JOCAS'da yayınlanmasına izin verdiği için teşekkür eder.

Makale ilk olarak, New York merkezli Social Science Research Council’ın (Sosyal Bilimler Araştırma Konseyi) sponsorluğunda 1993 yılında Washington DC'de Woodrow Wilson Center'da düzenlenen "Visions, Institutions, and Experiences of Imperial Russia (Öngörüler, Kurumlar ve Emperyal Rusya'nın Tecrübeleri)" adlı konferansta sunulmuştur.

Thomas M. Barrett, tarih profesörü, St Mary's College, St Mary's City Maryland, ABD. 
sonra çanlar çalınıyor, silahlar ateşleniyor, reçineye batırılmış kütükler alarm vermek için yakılıyor ve Kazaklarla kalelerde bulunan askerler hatta açılan yarığa doğru hücum ediyordu.

Kafkasya'daki askeri hatlara karşı dağların oluşturduğu "kaleler", Rusların bölgedeki tecrübelerinin ve Kuzey Kafkasya üzerine çalışmalar yapan Batılı tarihçiler ile Sovyet öncesi dönemin tarihçilerinin gün yüzüne çıkardığı imgeler ve ayrıştırma hatlarıdır. Bu hatlara Terek ve Kuban nehirlerinin Rusya tarafındaki "kıyı şeridi" de dâhildir. Ayrıca bunlar, Rusların, İran ve Osmanlı İmparatorluğu ile rekabet hatlarıdır. Bilindiği üzere, Rusya devleti 16. yüzyılda Kazan ve Astrahan'ı ele geçirip güneye doğru ilerlemeye başladı. ilk kaleler Kuzey Kafkasya'ya bu ilerlemeden hemen sonra inşa edildi. I. Petro'nun İran seferi (1722) sırasında başlayan geniş ölçekli mücadeleler, 18. ve 19. yüzyıllar boyunca Osmanlı İmparatorluğu ve İran ile Kafkasya topraklarında art arda yapılan savaşlarla devam etti. Kızlyar-Mozdok hattının kurulmasıyla (1769) başlayan askeri hatlar, Kuzey Kafkasya'nın içlerine, güneye doğru kaydı ve Rus kuvvetleri birbiri ardına kaleler inşa ederek dağların içlerine doğru ilerledi. Kafkas askeri hattının 1832 yılında tamamlanmasından sonra batıda, Karadeniz kıyısı boyunca uzanan bir hat daha oluşturularak Kafkas halklarının Karadeniz ve Osmanlı İmparatorluğu ile bağlantısı koparıldı. Burada yaşayan halklar, Rusların topraklarını ele geçirmesine gerilla savaşı ve büyük ölçekli yangınlar çıkararak karşılık verdi. Direniş, Şamil'in kutsal savaşıyla birlikte (1834-1859) doruk noktasına ulaştı. Nihayetinde Çerkeslerin direnişi 1864 yılında kırıldı, Kuzey Kafkasya'nın fethi tamamlandı ve bölge güvenliğin sağlandığı bir Rus kolonisi haline geldi.

Rusların Kafkasya'yı ele geçirmesiyle ilgili Batılı tarih yazıcılı̆̆ı, John Baddeley'in 1908'de yazdığı "The Russian Conquest of the Caucasus" ("Rusların Kafkasya'yı İstilası") adlı makalesiyle başladı. Geçtiğimiz yıllarda ise derleme makalelerden oluşan "The North Caucasus Barrier" ("Kuzey Kafkasya Seddi") ile Moshe Gammer'in "Muslim Resistance to the Tsar: Muslim Resistance to the Tsar: Shamil and the Conquest of Chechnia and Daghestan" (“Müslümanların Çar'a Direnişi: Şamil ve Çeçenya ile Dağıstan'ın Fethi") başıklı kitabı, Dağlıların Rus ilerleyişine karşı gösterdiği direnişi anlatan önemli bir ilk eser olarak yayınlandı. Ancak Rusya ve 
Kuzey Kafkasya tarihi, özünde askeri bir tarih anlatısı olarak kaldı. Tarihçiler hala buradaki hatları neredeyse aşılamayacak şekilde çizmeye devam ediyor. Burada bakış açısının değiştiği tek nokta Rus ilerlemesinin değil, Kafkasya direnişinin de odak noktası haline gelmesidir. $^{2}$

Iddia ettiğim üzere Rusların Kuzey Kafkasya'ya doğru ilerleyişi askeri bir harekâttan daha fazlasıydı. Bu ilerleyiş aynı zamanda çok sayıda insanın iç ve dış göçünü, yeni topluluklarının ortaya çıkmasını ve iskânını, bölgenin eski halklarının da tasfiyesini içeren bir sınır bölgesi (frontier) ${ }^{*}$ oluşum süreciydi. Tüm sınır bölgelerinde olduğu gibi sınırlar iç içe geçiyor ve ittifaklar Ruslar, Ukraynalılar, Dağılıar, Ermeniler ve Gürcüler arasında hiç durmadan değişiyordu. ${ }^{3}$ Rusların Kuzey Kafkasya'yı topraklarına nasıl kattı̆ı̆ını anlamak için askeri hatların gerisine, halkların devinimine, yerleşim yerlerine ve topluluklara, yer şekillerinin biçim değiştirmesine ve komşuların yalnızca savaştaki değil, günlük hayattaki etkileşimlerine de bakmamı gerekmektedir.

Devrim öncesi Rus tarih yazıcılığı bölgenin askeri açıdan ele geçirilmesi üzerine odaklanarak yönetim ve yeniden iskân politikalarını inceledi. Bu anlatıda bölgede yaşayan yerli halklar, kendilerine yalnızca Rus ilerlemesini kolaylaştırdıkları durumlarda yer buldu. ${ }^{4}$ Sovyet tarihçileri ise kendi bakış açılarından Kuzey Kafkasya halklarını inceledi ve bölgede yaşayan etnik grupların çoğunu temsil edecek ulusal tarihler yarattı. Bu tarih anlatısındaki eğilim ya Rus ordusunun bölgede yol açtığı yıkımı önemsizleştirmek ya bu yıkımı Kafkasya'yı kendi düşmanlarına karşı (İran, Osmanlı İmparatorluğu, Kırım Hanlığı) bir savunma harekâtı olarak yansıtmak ya da bunu, Kuzey Kafkasya'yı tarihi ilerlemenin ana çizgisine taşıyan, baskıcı ama nihayetinde ilerlemeci olan çarist "kolonyal politikaların" bir parçası olarak yorumlamaktı. ${ }^{5}$ Sovyet döneminde, Kuzey Kafkasya'daki göç, etnik

\footnotetext{
* "Frontier" terimi için Türkçede yerleşmiş bir karşılık bulunmuyor gibi görünüyor. Çeviride "sınır bölgesi" karşılığını kullandığımız frontier, sosyal bilimlerde "sosyal ve ekonomik koşulları orayı yurt edinmeyle belirlenen sınır bölgesindeki yerleşim yeri" anlamına geliyor. Frontier kavramını sosyal bilimler literatürüne sokan Amerikalı tarihçi Turner onu "vahşiliğin ve medeniyetin karşılaşma noktası" olarak tanımlıyor. (Frederick Jackson Turner, America's Frontier Story. A Documentary History of Westward Expansion. Huntigton, 1980, p. 18). (e.n.)
} 
çeşitlilik, bölgesel ekonominin gelişimi ile kentlere ve Kazaklara dair çalışmalar, genellikle Ruslarla Dağılır arasındaki yakınlık ve karşılıklı etkiyle ilgili şatafatlı iddialar içermekte, ancak sınır bölgesi yaşamının zorlukları, gerilimi ve şiddet barındırmasıyla ilgili gerçek gözlemlere yer vermemektedir. Bu çalışmalar yalnızca ufak tefek detayları kapsamaktadır. Bunlar da kaçınılmaz olarak "yakınlaşma" (sblijeniye) ve "halkların kardeşliği" (drujba narodov) temalarını ortaya çıkarmaktadır. ${ }^{6}$

Sovyet tarihçileri Rus sınır bölgelerini sblijeniye alanları olarak tanımlasalar da Batılı tarihçiler bölgeyi ya koloni ya da sıradan bir sınır olarak gördü ya da hiç görmemeyi tercih etti. Batılı tarihçilerin, Rus tarihini sınır bölgeleri sürekli genişleyen bir yapı olarak betimleyen sayıca az çalışması, büyük ölçüde meta-tarihsel ve Turneryen bir bakış açısına saplanıp kaldı. Merkezden uzaktaki yaşamın nasıl olduğundan çok devletin ruhuyla ilgilendi ve çok az yardımcı araştırmayla desteklendi. Rus tarihinin tamamı Kiev'den başlayıp Sibirya'da sonlanan sınır bölgeleri tarihi olarak sunuldu. Bu anlatıda Rusların göç sürecinin farklı dönemleri arasında çok az fark olup Kafkasya (genellikle de Aşağı ve Orta Volga) göz ardı edilmektedir. Bununla birlikte, Rus sınır bölgesini basitçe Amerikan sınır bölgesiyle özdeşleştiren çalışmalar da yapıldı. Bunlarda Kazan, St. Louis yerine koyuldu ve Novgorod'un alınması, Amerikalıların İngilizlerden Ohio'yu almasına benzetildi. Ukrayna'nın fethi de Amerika'nın Louisiana'yı satın alması ile karşılaştırıldı. ${ }^{7}$ Çok az tarihçi bu konuda daha temkinli davrandı. Ancak bu tarihçiler de kolonizasyonun doğuya yönelmeden önce doğruca güneye yöneldiği ve on sekizinci yüzyılın sonuna dek Aşağı Volga'nın en az Sibirya kadar Rusya'ya ait olmadığı gerçeğini göz ardı ederek hemen Kazan'dan Sibirya'ya atladı. ${ }^{8}$ Benzer şekilde göç hareketleri, kolonizasyon ve sınır bölgesi toplumu üzerine yapılmış önde gelen araştırmalar, büyük ölçüde Sibirya'ya, bozkır sınır bölgelerine ve Ukrayna ile Kırım'daki yerleşimlere yoğunlaşmıştır. Bu göç hareketlerinin aslında daha büyük ve muhtelif süreçlerin bir parçası olduğu (ve elbette bozkırların Kafkasların eteklerine kadar uzandığı) genellikle unutuldu. ${ }^{9}$

Rusya'ya ait olmayan sınırlarda genişleyen sınır bölgeleri üzerine son zamanlarda oldukça değerli çalışmalar yapılmıştır. Kısmen yapılan bu çalışmalar sayesinde Rus tarihçileri, sınır bölgelerini 
ilerlemenin lokomotifi olarak kabul eden Turneryen bakış açısıyla artık ilgilenmemektedir. ${ }^{10}$ Ancak bu çalışmalar da Ukrayna, Kırım, Volga ve Sibirya'daki sınır topraklarının Rusya'ya ait olan bölgelere dönüştürülmesini toplumsal olmaktan çok siyasi bir süreç olarak tanımlamaktadır. Bu konuyla ilgili bilgimiz toprakların ele geçirilmesi (savaş ve yönetim) ile sınırlıdır. Ancak Rus kolonizasyonunun "kurucu" yönleri (yeni toplumsal kimlikler, etnik ilişkiler, yer şekilleri, bölgesel ekonomiler ve maddi kültür yaratımı) henüz keşfedilmemiştir. Ayrıca toplumsal tarih çalışmaları da büyük ölçüde "mağlup" tarafa ve bu tarafın boyun eğdirilmesi, direnişi, yok edilmesi ve göç hareketleri üzerine yoğunlaşmaktadır.

Sınır bölgelerinin incelenmesine yönelik Kuzey Kafkasya ve başka yerlerde bulunan Rus sınır bölgelerini açıklamak amacıyla kullanılacak bakış açısını tespit etmek için son yirmi yılda Amerikan sınır bölgesi tarih yazıcılığındaki gelişmelerden yararlanılmalıdır. Turneryen bakış açısının sınır bölgesi tarihini anlatırken ileri sürdüğü Batıdaki "boş" topraklara yönelen ve bu süreçte muhteşem bir Amerikan bireyselciliği ile demokrasisi ortaya çıkarmış özgür beyaz yerleşimciler tezi nihayetinde bir kenara bırakılmıştır. Bu bakış açısının yerine tarihçiler artık farklı renk ve uyruklardaki halkları, çevre manipülasyonunu, kültürel harmanlamayı, toplumsal tabakalaşmayı ve efsane yaratımını içeren karmaşık bir süreçle ilgili çalışmalar kaleme almaktadır. ${ }^{11}$ Amerikan ekolünün tarih yazıcılı̆ı̆ının sınır bölgesi incelemelerinde benimsediği ve özellikle çevre tarihi, toplumsal tarih ve etnotarih başlıkları altında toplanan üç eğilim Rus tarihçiler tarafından da kullanılabilir. Bu makale, bu başlıkların tamamını derinliğine incelemeyi amaçlamamakta, ancak Rusya'nın sınır bölgelerinden birine yönelik bakış açısını kavramsallaştırmayı ve böyle bir kavramsallaştırmanın ortaya ne çıkaracağını genel hatlarıyla incelemeyi amaçlamaktadır.

\section{Çevre Manipülasyonu ve "Yer Değiştiren Türler"}

Amerikan Batısının ekonomik gelişimi, yaratım olduğu kadar yok etme yolunu kullanarak yalnızca doğaya saldırı değil aynı zamanda yabancı organizmaların (mahsullerin, tohumların, hayvanların ve mikroorganizmaların) da yeni ekosistemlere doğru yer değiştirmesiydi. Toprağa yönelik yerel bakış açısının yerini toprağı bir 
meta olarak gören Avrupalı bakış açısı almıştı. Kaynak yoğun ekstansif yetiştirme teknikleri, ekolojiye zarar vermeyen küçük ölçekli yöntemlere baskın geldi. William Cronon, George Miles ve Jay Gitlin'e göre "eskinin yeniden üretilmesi ve yeninin kucaklanması arasındaki bildik sınır bölgesi gerilimi, gittikçe Avrupalı bir görünüm kazanan yeni yerleşimlerin oluşturduğu yer şekillerinde ve Yeni Dünya'nın ekosistemiyle daha uyumlu yeni siyasal ekonomide kendini gösterdi." ${ }^{12}$

Yerleşimciler, tanımadıkları bir çevrede yeni topluluklar inşa etmeye çalıştığından çevre tarihi bir sınır bölgesini anlamak için özellikle önemlidir. Yer şekillerinin yerleşimcileri, yerleşimcilerin de bu yer şekillerini nasıl dönüştürdüğü, buraya gelen insanların mücadelelerine ve fırsatlarına içkin parçalardır. ${ }^{13}$ Kuzey Kafkasya'nın çevre tarihi özellikle karmaşık bir yapıya sahiptir. Bu denli sert ve çeşitli hava koşulları dünyada pek az yerde görülür. Bölgedeki dağ zirvelerinde ve eteklerinde çok sayıda mikro iklim, su baskını döngüleri, vadilerde yaşanan kuraklıklar, dağ ile bozkırın birleşmesi (Hazar Denizi'nin kıyısı boyunca uzanan yarı çöl) gibi çok farklı hava koşulu bulunmakta ve bataklıklardan oluşan Terek ovası yer almaktadır. Bölge deveyi öküzle, dağ keçisiyle mandayı birlikte görmenin mümkün olduğu bir yerdir.

Pek çok farklı ve sert koşula sahip olan bu çevrede kolonistler, Amerikalıların tecrübesinin aksine, hastalıkların taşıyıcısı olmaktan çok kurbanları oldular. Rusya'nın Kafkasya'nın Karadeniz kıyısını topraklarına katma sürecinin felakete dönüşmesinin nedeni, bölgenin sabanla ya da Rus bağışıklık sistemiyle kısa sürede ehlileştirilemeyecek bir toprak yapısına sahip olmasıydı. Sayısız ölüme neden olan Rus yerleşim tarzı, ekolojiye duyarlı geleneksel tarzın tam tersiydi. Bölgedeki Çerkesler dağ eteklerine ve daha yükseklere yerleşerek kıyıda sıtmanın yayıldığı bataklıklardan ve mahsule zarar veren sisten uzaklaşmıştı. Ancak Rus yerleşimi kıyıda ve deniz seviyesinin altında akan nehirler boyunca başlamıştı. Bu yerleşim yerlerine yiyecek maddeleri ya Karadeniz üzerinden gemilerle taşınarak ya da Çerkeslerle yapılan ticaret yoluyla geliyordu. Bununla birlikte hem Karadeniz kıyısı boyunca hem de Karadeniz Kazaklarının yaşadığı Kuban bölgesine kurulan kalelerdeki ölüm oranı, veba, sıtma, tifo, iskorbüt ve koleradan hayatını 
kaybeden yerleşimciler ve askerler sebebiyle oldukça yüksekti. 1840 'lı yıllarda Karadeniz kıyılarında subay olarak görev yapan G. i. Flipson, düşük rütbeli askerlerin bir yıl içerisinde yüzde 16'sının öldüğü Sohum şehrinin (bu rakam bölgedeki ortalama yaşam süresini altı yıla indirmektedir) "taştan mezar" olduğunu söylemektedir. Bu rakam Kuban bölgesinde bulunan büyük yerleşim yerlerinde görülen ölüm oranlarıyla aynıydı. Bunun tek istisnası, 1848 yılında bölgeye yerleşen 2000 ailedeki erkeklerin yüzde 36 'sının çoğunlukla kolera sebebiyle hayatını kaybetmesiydi. Bölgedeki yüksek hastalık oranı nedeniyle bu dönemde Kuzey Kafkasya'da kaplıca işletmelerinin açılmaya başlaması ironiktir. Puşkin'in en sevdiği kaplıca olan Pyatigorsk, önceden Konstantinogorskaya Kalesi'ydi. Hasta askerler ve Kazaklar bu kaleye 1780 yılında Kalmuk çadırları altına kurulan sıcak su kaynaklarından yararlanmak için giderlerdi. ${ }^{14}$

Kuzey Kafkasya'nın zengin bozkırlarında Ruslar büyük bir başarıyla tarım ekonomisini kurup, iskânı ve siyasi kontrolü sağladı. Ancak tüm bunları hayata geçirmek bir yüzyıldan daha uzun sürdü. 1833 gibi geç bir tarihte bile Stavropol'de yaşanan kıtlık Rusya hükümetini, devletin bölgeye yerleştirdiği devlet köylülerine buğday almaları için üç milyon ruble kredi vermeye zorladı. Ayrıca hükümet 40 bin köylünün geçici olarak Rusya içlerine dönmesine izin verdi. ${ }^{15}$ Böylece Rus kontrolü, oluşturulan siyasi ekonomiyle birlikte başarıya ulaştı. Bu yeni ekonomi modeli ana kültür merkezlerinden radikal biçimde farklıydı ve Kazaklara, devlet köylülerine, yerel halka (serflere değil) ve çeşitlendirilmiş bir ekonomiye dayanıyordu.

Bozkırı kolonileştirme planları 1764'e kadar gidiyordu ve bu tarihi izleyen yıllarda ilk kez geniş toprak bağışları yapılmıştı. Ancak pek çok toprak sahibi mülklerini ya satmış ya da ihmal etmişti. Bölgeye yerleşenler ise tarımla uğraşmayıp topraklarını önce büyükbaş hayvanlar için otlak olarak kullandı. En büyük başarısızlıklardan birini Prens A.A. Vyazemski yaşadı. II. Katerina'nın gözdelerinden olan prens, 1783-1786 yılları arasında Kafkas bozkırlarında 765 bin dekardan fazla toprağın sahibiydi. Mülkünün merkezi olarak Çernıy Rınok (Karapazar) adında bir kasaba kurdu ve bin serfini buraya yerleştirdi. Büyük ölçekli buğday yetiştirme teşebbüsü, köylülerine deniz balıkçılığı ile bağcılığı öğretme teşebbüsleri gibi başarısız oldu Ardından mülkünü başka bir soyluya sattı. Bu kişi de toprakları 
parçalara ayırdı ve büyük çoğunluğunu elden çıkardı. On dokuzuncu yüzyıl başlarında Çernıy Rınok 50 köy evinin olduğu sefil bir yerleşim yerine dönüşmüştü. ${ }^{16}$

Sovyet tarihçileri, derebeylik (pomeşçik) ekonomisinin başarısızlığında sermaye yetersizliğini başlıca etken olarak görseler de çevresel etkenler de önemliydi. İskân edilen köylüler yeni iklim koşullarına, hastalıklara ve yeni tarım takvimine uymakta zorlanmış, pek çoğu hastalanmış ya da hayatını kaybetmişti. Pokoynoye köyü 1766 yılında güney illerinden Kuma Nehri'nin kıyılarına gelen köylüler tarafından kuruldu. Burada yaşayan köylülerden birine göre, köy "sıtma" hastalığından pek çok insan öldüğü için bu adı almıştı (hayatını kaybedenler pokoyniki yani "göçenler" oluyordu). ${ }^{17}$ Nogay Tatarları ise bu köye "maraz yer" derdi.

Peki, yerel tarım ile Rus tarımı arasındaki kesişim noktasında meydana gelen şey neydi? Rus yetkililer dağ eteklerinde ve zirvelerde yapılan tarımı ilkel olarak görme eğilimindeydi. Oysa hafif saban, taraçalı yamaçlar, sulama sistemleri, sofistike gübreleme ve bölgeye uyum sağlamış buğday türleri, çevreye dost ve intansif tarıma uygun olup, Rus ekstansif tarımına göre pek çok yönden üstündü. Özellikle Dağıstan'da yapılan tarım intansifti. Bölgede oldukça kaliteli sulama sistemleri bulunuyor, gübre, kül, ince kum, hayvan gübresi ve ot ile karıştırılmış saman ve kuş gübresi gibi çok çeşitli gübre de yaygın olarak kullanılıyordu. Sovyet tarihçileri yerel tekniklerin ve mahsullerin Ruslar arasında yaygın şekilde kullanıldığını, Rus mahsullerinin ve tekniklerinin Dağlılar üzerinde etkili olduğunu iddia etmektedir. Ancak, en azından on dokuzuncu yüzyılın ortalarına kadar, bu etkinin güneyden Ruslara doğru gelmiş olduğu anlaşılıyor. Kızlyar şehri, İran'dan gelen pirinç ve darı, Derbent buğdayı ve en önemlisi de üzüm asmaları ile bölgeye özgü sulama kanalları olmadan hiçbir zaman büyük ve kalıcı bir yerleşim yeri olamazdı. Ekstansif tarımın yapıldığı Kuzey Kafkasya bozkırında bile çiftçiler Kuban buğdayına muhtaçtı. ${ }^{18}$

Peki, Rus kuvvetlerinin yol açtığı çevre felaketi, dağlardaki nüfusun direnişinin kırılmasında ne kadar büyük bir rol oynadı? Tolstoy'un "Ağaç Kesimi” öyküsü ile ünlenen ağaç kesimi yalnızca düşman kabilelerin gizlenmek amacıyla kullandığı ormanlık alanları azaltmak için değil, aynı zamanda bölgedeki insanları zaten kıt olan 
inşaat ve yakacak malzemelerinden mahrum bırakmak için de önemli bir araçtı. Baddeley'e göre, Şamil'in Çeçen topraklarında ağaç kesimine getirdiği kısıtlamalar Rus baltasına karşı bir savunma amacı güdüyordu. Ancak bölgede yalnızca Ruslar ağaç kesmiyordu. Ağaç ve ağaç ürünleri (ev, fıçı, kağnı, tekerlek, asma kazıkları ve kasnak yapımında kullanılan kereste) Çeçenlerin ve Kabardeylerin Rus yerleşimcilere sattığı başlıca mallardı. 1840'a kadar Kafkas askeri hattına en yakın bölgede yaşayan Çeçenler yılda 500 ila 800 arasında değişen sayıda, kereste ve yakacak odun dolu salı Sunja ve Terek nehirlerinden Kızlyar'a gönderiyordu. Bununla birlikte Çeçenler, asma kazığı taşıyan 5 bin ila 6 bin kağnıyı da aynı güzergâha yolluyordu. Rusların ağaç intiyacı o kadar fazlaydı ki (ayrıca bozkır ve dağlar arasında kalan erişilebilir ormanlar da bir o kadar azdı) bazı bölgelerde yerel halkın gereğinden fazla ağaç kesmesine neden olmuş olmalıdır. ${ }^{19}$

Ağaç kesimi elbette Rusları da etkilemişti. Coğrafyacı D. L. İvanov da Rus iskânı ve bölgedeki ormanların yok edilmesi sonucunda 1886 yılında Stavropol'de büyük bir toprak erozyonu olduğunu yazar. Dubovka (meşe) ve Berestovok (huş ağacı kabuğu) gibi yerleşim yerleri, isimlerini etraflarında bulunan ormanlardan aldı, ancak bu yerleşim yerleri sonradan çıplak alanlar haline geldi. Ağaçların, çalıların ve vahşi yaşamın yoğun olduğu çoğu yer, çok kısa sürede çıplak bayırlara, yarıklara, vadilere ve ayrık otlarıyla kaplı alanlara dönüştü. 1790 yılında kurulduğunda Kruglolessnoye (Ormaniçi) köyünün çevresi geniş ormanlarla çevriliydi. On dokuzuncu yüzyılın sonunda, köyün batı tarafında bu ormandan geriye yalnızca "içler acısı kalıntılar" kalmış ve köy yerel halk tarafından yalnızca Krugloye (İçköy) olarak bilinir olmuştu. 1799 yılında Rus yerleşimciler tarafından kurulan Çernolesskoye (Karaorman) köyünün de buna benzer bir hikâyesi vardır.

Bir zamanlar bu köyde yaşayanlara göre, köy kurulduğunda etrafında Tomuzlov nehrinin kıyısında yetişen uzun ağaçlar vardı. Bu orman özellikle yaprak döken ağaçlardan oluşuyordu. Ormanda çok sayıda yaban domuzu ve yaban keçisi bulunuyordu. Hatta Kafkas dağlarından gelen ayı ve geyikleri bile bu ormanda görmek mümkündü. Günümüzde bu ormandan geriye tek bir ağaç bile kalmadı. ${ }^{20}$ 
Yeni kurulan Rus yerleşim merkezleri için bu denli zenginliğe sahip olan doğanın önemini azımsamak yanlış olacaktır. Görüldüğü üzere, kurulan Rus köylerinin isimleri bu zenginliğin izlerini taşımaktadır (Obilnoye, Blagodatnoye - bol, zengin; Medvedskoye ayı; Orehovskoye - cevizlik; Gruşevskoye - armutluk). Elbette ormanlarda görülen aşırı kesimin yol açtığı sonuçların etraflıca incelenmesi gerekmektedir.

Ağaç kesiminin Dağlıların direnişini kırmasından ve yerel ekonomiyi dönüştürmesinden daha önemli olan şey, kışlık otlaklara ve ovalarda bulunan tuz göllerine girişin yasaklanması ya da kısıtlanmasıydı. Hayvanların otlatılması genellikle ekstansif bir faaliyetti. Farklı köyler, emek ve kaynaklarını birleştiriyor ve sığır çobanları, hayvanları yaşadıkları yerlerden 400 kilometre kadar uzaktaki kış otlaklarına götürüyordu. Bunun yanı sıra kırılgan ekoloji dağ ekonomisini de kısıtlıyordu. Bu kırılgan çevre koşullarının diğer özelliği ise ekilebilir toprakların az olmasıydı. Ancak yerel halkın tamamı büyükbaş hayvanları ve atları beslemek için bile olsa tarıma intiyaç duyuyordu. Bu ekonomi işgalci askeri kuvvetlerin kolayca zarar verebileceği bir ekonomiydi. Böyle olmasına rağmen hem Rus kaleleri hem de yerleşimciler, sabanın bozkır üzerindeki galibiyetine kadar bu ekonomiye muhtaçtı.

\section{Sınır Bölgeleri Arası Mübadele}

Bu terimi ilk kez Daniel H. Usner, Jr. Indians, Settlers, \& Slaves in a Frontier Exchange Economy: The Lower Mississippi Valley Before 1783 (Sınır Bölgeleri Arası Mübadele Ekonomisinde Kızılderililer, Yerleşimciler ve Köleler: 1783'ten Önce Aşağı Mississippi Vadisi) adlı kitabında kullanmıştır. Usner, mübadeleyi "küçük ölçekli üretim, yüz yüze pazarlama ve sıradan geçim kaynaklarının özelliklerini" içeren "yerel ve kolonyal grupların mal ve hizmetlerinin devinim halinde olduğu kültürlerarası etkileşim ağı" olarak tanımlamaktadır. ${ }^{21}$ Bu tür süreçler merkezde yaşayan insanlar açısından önemsiz görünse de sınır bölgelerinde yaşayan insanlar için bölgesel ekonominin ve ortak kültürün temelini oluşturuyordu. Sınır bölgeleri arası mübadele, elbette, bunların tamamında yaşayan yerleşimciler (ve işgalciler) için hayati önemde olup yerel halk ile kolonistler arasındaki etkileşimin 
ve bağımlılık ilişkilerinin oluşturulmasına yardım ediyordu. Rus ve Kuzey Kafkasya tarihi, sınır bölgeleri arası mübadelenin neye evirildiğine odaklanmıştır. Bu odak, Sovyet bakış açısıyla söylersek, mübadelenin "Kuzey Kafkasya'yı Rus pazarına çekmek" olduğudur. Her iki anlatı da mübadelenin, bölgedeki toplum, ekonomi ve kültür açısından ne ifade ettiğine yoğunlaşmamaktadır. ${ }^{22}$

Kuzey Kafkasya'daki yerel ticaret kalelerde, Kazak köylerinde ve ticaret noktalarında, dağlarda ise gezici Ermeni tüccarlar aracılı̆̆ıyla yapılıyordu. Bu ticaret şekli bölgede oldukça yaygınlaşıp gelişmeye devam etti. Bu gelişim, bölgeyi ele geçirmek için 1840 'lı ve 1850 'li yıllarda yapılan savaşların zirvede olduğu dönemde dahi durmadı. Dağlılar, tuz, balık, havyar, pamuklu kumaş, demir ve kurşun ürünler ile sanayi ürünleri karşılığında çiftlik hayvanları, buğday, odun, silah, koyun postu, kıyafet ve deri ürünler gibi çok çeşitli ürünün ticaretiyle uğraşıyordu. Esir alma ve fidye de yerel ticaretin bir parçasıydı.

Rusların Kuzey Kafkasya'daki deneyimlerini anlamak için sınır bölgeleri arası mübadelenin bazı yönlerini incelemek gerekmektedir. Her şeyden önce, Ruslar, on dokuzuncu yüzyılda yerel halkın sanayi ürünlerine karşı bağımlılığını arttırmayı hedefledi. Böylece bölge halkı "medeniyetin meyvelerinin" tadına boyun eğecekti. Ancak on sekizinci ve on dokuzuncu yüzyıldaki yerel ticarete bakıldığında kimin kime bağımlı olduğu sorusu daha karışık bir hal alacaktır. Rusya, bölge halkının Rus tüccarların zenginleşmesi için kürk ve pamuk gibi yüksek miktarda hammadde sağladığı Kuzey Kafkasya'da hiçbir zaman bir ticaret kolonisi oluşturmayı başaramadı. Sınır bölgeleri arası mübadelede yerel düzeyde imal edilen kıyafetler, silahlar, eyerler ve diğer deri ürünleri ile günümüzde işlenmiş yiyecek (kurutulmuş meyve) dediğimiz ürünler ile bahçede yetişen özel ürünler (cevizler, kökboyası, taze meyve) önemliydi. Yani Rus buğdayı gibi çok yüksek miktarda üretilen ham maddelerden ziyade üretimi yüksek seviyede beceri gerektiren ürünler daha önemliydi.

Ana kültür merkezinden birtakım sebeplerle teknik olarak daha sofistike olan bu uzak sınır bölgelerinde bağımlılık hatları daha karmaşık olabiliyordu. Rusların Kafkasya'yı işgali sırasındaki ilginç ayrıntılardan biri de Kazakların sahip olduğu silahların dağlarda yaşayan gümüşçüler ve demirciler tarafından temin edilmesiydi. Kazakların kullandığı silahlar olan süvari kılıcı (şaşka), kama (kinjal) ve 
on dokuzuncu yüzyılın ortasına kadar da dağ tüfeği genellikle dağ köylerinde üretiliyor ve ticaret yoluyla elde ediliyordu. Bu durum, Kuzey Kafkasya askeri hattında zanaatkarların yaptığı üretimin de altını oydu. Hat boyunca yaşayan Rus ve Kazaklar metal zanaatlarıyla uğraşmıyor, metal gereçleri güneyden ya da kuzeyden satın alıyordu. Demirci ve gümüş̧̧üler gibi yerli zanaatkârların Rus kale ve yerleşim yerlerinde ticaret yapması hoş karşılanıyordu. Kızlyar ve Mozdok'taki çoğu zanaatkâr Terek'in dışındandı. ${ }^{23}$ Bununla birlikte Rus kalelerinin tamamı on dokuzuncu yüzyılda ekonomik temellerini, ticaret, tarım, ipek böcekçiliği ve çeşitli zanaatlarla uğraşan Ermeni, Gürcü, Çeçen, Kabardey ve başka hakların yerleşimlerini cezbederek genişletmeye çalıştı.

Sınır bölgeleri arası mübadelenin incelenmesi gereken ikinci özelliği, çoğunlukla başarısız bir hamle olarak kalan, Rus ve yerli halk arasındaki yapılan ticareti, ticaret noktaları ve tuz dükkânlarının oluşturduğu karantina hatlarıyla düzenleme girişimiydi. Yeraltı ekonomisinin ortaya çıkması için oldukça verimli olan bu bölgede, kaçakçılar sık sık gümrük hatlarını aşıyor ve karaborsanın ortaya çıkması da kumpas ilişkilerine yol açıyordu. 1820'lerde bölgedeki ticaret noktalarından birine teftişe gelen bir müfettiş, Kabardey içlerinde Kazak kaleleri kurulduktan sonra yedi karantina noktasında başlıca ticaret malı olan tuz ticaretinin neredeyse durduğunu kayıtlara geçirmiştir. Kazaklar, tuzu başka köylerden getiriyor ve karantina noktası olmayan yerleşim yerlerinde Kabardeylere ve başka halklara satıyor ya da ticaret yapıyordu. Günümüzde, yapılan tahminlere göre kaçak ticaretin değeri, Dağılıarla yapılan resmi ticaretin iki katından fazlaydı ve kaçakçılık normal bir faaliyet olarak görülüyordu. ${ }^{24}$ Kontrolsüz ticaret, pazar ticareti, iç köylere kadar giden ve Kafkas dillerini konuşabilen Ermeni tüccarların varlığı Rus ticaret noktalarının da sonunu getirmişti.

Üçüncü olarak, Rus talep akışının yerel ekonomik düzeni nasıl etkilediğini anlamamız gerekmektedir. Ticaret mallarının sayısı zamanla arttığından yamçı, çerkeska ve kalpak gibi kıyafetlerin ve el işi malzemelerin ticaretinin de yerel ekonomiyi güçlendirmiş olduğu görülüyor. Ancak uzmanlaşmanın kendine göre avantajları da vardı. Kızlyar komutanı A. İ. Ahverdov, 1804 yılında Kumukların yaşadığı Endirey köyünün, Dağlılardan esir satın alarak üzüm bağlarında 
sözleşmeli işçiler olarak çalışmaları için bu esirleri karlı fiyatlara Kızlyar'a satmasıyla "zenginleştiğini” bildiriyordu. Dağ eteklerinde adeta bir kapı görevi gören Endirey köyü, bu kazançlı ticaretten faydalanmak adına oldukça iyi bir konumdaydı. Bu durum Rus kalelerinin, bağcılığı geliştirmek için yerlilerle esir ticareti yapacak kadar "yerlileştiğini" göstermekte, aynı zamanda bölgedeki Rus varlığının yerel ekonominin parçalarını yeniden düzenlediğini ve bu ekonomide yer alanlar için zenginlik kaynağı yarattığını ifade etmektedir. ${ }^{25}$

Ruslar da yerli halkın esir alma geleneklerini benimsedi. Esir ticaretinin Ruslar tarafından gönülden kınanmasına, 1804 yılında yasaklanmasına ve nihayetinde tamamen durmasına karşın, Ruslar bölgede esir alma ve fidyeye yönelik yapılan yerel faaliyetlere boyun eğmek zorunda kaldı (büyük intimalle esir ticareti, Kuzey Kafkasya'nın dar ekonomisinde oldukça önemli bir gelir kaynağıydı). Kaleler, anlaşma yaptıkları kabilelere karşı resmi bir güvenlik garantisi olarak yerel esirleri (amanat) tutuyordu. Bununla birlikte bir esirin ölmesi ve yeni esirin verilmemesi durumunda kalelere, dışişleri konseyi tarafından başka bir esirin ele geçirilmesi izni de veriliyordu. Rus akıncı gruplar tutsak almak ya da esirlerin veya çalınan çiftlik hayvanlarını kurtarmak amacıyla görevlendiriliyordu. Ancak bu durum, ara sıra yağmaya da dönüşüyor, Dağlıların Rus yerleşimlerine yaptıkları saldırılara benziyordu. ${ }^{26}$

\section{“Ara Zemin" ve Etnik Sınır Bölgeleri}

Amerikan sınır bölgeleri üzerine tarih yazıcılığının Amerikan yerlilerine yönelik söylemi son elli yılda kökten bir değişim geçirdi. Önceden tarih yazımının neredeyse hiç görmediği yerliler, daha sonradan sömürülen, yok edilen ve asimilasyona uğratılan kurbanlar oldu. Son yirmi otuz yıldır, etnotarih beyazlarla yaşadıkları çatışmaları ve geleneksel kültürlerini korudukları koruma "adacıklarını" vurgulayarak Kızılderililerin direnişçiler olarak tanımlanmasına yol açtı. George Miles, Amerikan yerlilerinin kendi tarihlerinin oluşmaya başlamasına karşın, yeni yapılan bu çalışmaların küçük ölçekte kaldığından dem vuruyor: "Bazı araştırmacılar Kızılderili ve beyaz kültürlerini karşıt terimler olarak tanımlayarak Kızılderili tarihini, Amerikan tarih yazıcılığının ana 
akımına dâhil edebilecek bir yaklaşımın ortaya çıkabileceği düşüncesini neredeyse imkânsız kılıyor." ${ }^{27}$ Rusya İmparatorluğu'nda yaşayan, ancak Rus olmayan insanlar üzerine o kadar çok temel çalışma yapılması gerekiyor ki sınırda yaşayan insanlar ile ulusal azınlıklar hakkındaki çalışmalar da aynı marjinalleşme riskini taşıyor. İyi bir sınır bölgesi tarihi, diyelim ki, yalnızca Kafkasya ya da Karelya tarihi için önemli değil, aynı zamanda bir bütün olarak Rus tarihi için de önemlidir.

Rus yerleşiminin ilk aşaması boyunca oluşturulan sınır bölgeleri, çevredeki yeni Rusya olarak görmektense tüm tarafların yer aldığı kültür paylaşımı temelinde özgün bir yaratım olduğunu görmek oldukça temel bir meseledir. Rus devleti ve Rus yerleşimciler bölgede hâkimiyet kurmadan önce, insanlar arasında ister istemez ödünç alma görülüyordu. Richard White'ın, "The Middle Ground: Indians, Empires, and Republics in the Great Lakes Region, 1650-1815" (Ara Zemin: Büyük Göller Bölgesinde Kızılderililer, İmparatorluklar ve Cumhuriyetler) başlıklı önemli kitabında açıkladığı üzere, sıkça kullanılan kültürel etkileşim terimi, bir grubun, bir başka gruba ait münferit kültürel özellikleri ödünç alarak gittikçe o gruba benzemeye başladığı süreci tanımlar. Kültürel etkileşim, dominant grubun, boyun eğen bir gruba, doğru davranışın ne olduğunu dikte edebilmesi durumunda meydana gelmektedir." White'ın bu terimin yerine kullanılmasını önerdiği terim ise "ara zemin" kavramıdır. Ara zemin, tam aradadır: "kültürler arasında ve insanlar arasındaki zemin ile imparatorluklar ve köylerin devlet içermeyen dünyası arasındaki zemindir." Bu zemin, Avrupalıların istilası ve işgalinin içerdiği önplan ile Kızılderililerin yenilgiye uğraması ve geri çekilmesi arasındaki alandır. ${ }^{28}$ White'ın ara zemin kavramı evliliği, şiddete karşı uzlaşıyı, ritüeller aracılığıyla sürdürülen ittifakları ve ticaret aracılığıyla oluşturulan sosyal ilişkileri içermektedir.

Elbette, on yedi ve on sekizinci yüzyıllar ile on dokuzuncu yüzyılın başlarında, Ruslar ve Kafkasya'da yaşayan yerli halk arasında da böyle bir ara zemin bulunuyordu. Bu zemin büyük ölçüde farklı unsurlar arasında kurulan evlilik ilişkileri, sınır bölgeleri arası mübadele ve dağda yaşayan insanların konukseverlikleri aracılığıyla ortaya çıkmıştı. Kuzey Kafkasya'nın ara zemini, şahısların genellikle asker kaçağı olarak, firar ederek ya da esaret yoluyla etnik sınır 
bölgelerini aşıp yerlileşmesi ya da Ruslaşması sürecinin yaşandığı kültürel etkileşim bölgelerine dönüştü. Tarih yazıcılı̆̆ı, ara zeminin ne olduğuna, askeri hatlar ile etnik tipleme hatlarına nasıl indirgendiğine odaklanmaktadır. ${ }^{*}$ Burada ilgimi en çok çeken ve bu makalenin geri kalanında açıklayacağım kavram ise, akışkan etnik sınır bölgelerinin oluşmasına ve Kuzey Kafkasya'da muazzam bir ara zeminin ortaya çıkmasına yardım eden belirsizlik hatlarıdır.

Ara zeminin oluşması için ihtiyaç duyulan ön koşullardan biri "doğru davranışın ne olduğunu dikte edebilen dominant grubun" olmayışıdır. On sekizinci yüzyıl boyunca Kuzey Kafkasya'da görülen de buydu. 1864 yılından sonra bile Ruslar, bölgenin büyük bir kısmına davranış kalıplarını dikte edemiyordu. Ayrıca Ruslar bölgede bazı enklavlar haricinde etnik olarak dominant değildi. Kaleler sürekli savaş halinde bulunuyor, yerleri değiştiriliyor, terk ediliyor ya da yeniden inşa ediliyordu. Örneğin 1567 yılında Sunja Nehri'nin ağzına inşa edilen ilk Rus kalesi, saldırılardan sonra dört kez yer değiştirmek zorunda kalmıştı. Garnizon 1653 yılında Terskiy Gorod'a kaydırılınca da bu kale tamamen terk edildi. Terskiy Gorod kalesi de daha sonra taşınmış, kuvvetler 1722 yılında Svyatoy Kalesi'ne kaydırılınca terk edilmişti. Svyatoy Kalesi'nin kuvvetleri de 1735 yılında Kızlyar'a kaydırılmıs, bu kale de tasfiye edilmişti. 1778 yılında Kızlyar-Azak hattının kurulmasından sonra bile bölgedeki Rus varlığı akışkandı. Vladikavkaz, 1784 yılında, yani kurulduktan iki yıl sonra Mansur isyanı nedeniyle terk edildi ve ancak 1803 yılında yeniden inşa edilebildi. 1777 yılında ilk önce dağ eteklerindeki Orta Terek'te Yekaterinograd'ın sürekli değişen kaderi ise başka bir örnektir. 1785 yılında Yekaterinograd, kendine yakışır bir azametle Kazak köyünden Kafkasya Genel Valiliği'nin (namestniçestvo) merkezine dönüştürüldü. Genel Vali P. G. Potemkin (daha ünlü Potemkin'in kuzeni) ikametgâhını buraya taşıdı. Lüks bir malikâne yaptırıp,

Etnik sınır bölgelerini aşan insanlar üzerine çalışan az sayıdaki tarihçi "başka bir grup tarafından dâhil edilme" kavramını kullanmaya eğilimlidir. Insanların yaptıkları seçimleri araştırmadan yapılan bu çalışmalardaki yaklaşım, özne olması gereken bu insanları tarihin manipule edilmiş nesnelerine dönüştürmeye devam etmektedir. Örneğin, Gogol'ü, Ukrayna sınır bölgesinden "dâhil edilmiş" elit bir toplum üyesi olarak kabul etmek mümkün müdür? 
üzerinde "Gürcistan'a gider" yazısı bulunan klasik tarzda, muazzam büyüklükte, hantal kornişli, dört sütunlu bir zafer takı inşa ettirdi. iki yıl sonra merkez Georgiyevsk'e, ardından 1802'de Astrahan'a taşındı. Yekaterinograd, tarlaların ortasında büyük bir zafer takı olan terk edilmiş bir Kazak köyü olarak kaldı. ${ }^{29}$ Taşınmanın gerekçesi olarak Yekaterinograd'ın uzaklığı gösteriliyordu. Şüphesiz bu karara Mansur'un hat boyunca yaptığı akınlar da etkili olmuştu. Kuzey Kafkasya'nın başkenti olması tasarlanan bir sonraki kale Stavropol ise Rusya'nın geri kalanından daha ulaşılabilirdi ve bozkırın ortasında güvenli bir konumdaydı.

1818-1819 yılları arasında kurulan Groznaya (Tehditkâr), Pregradnıy (Bariyer), Zlobnıy (Marazlı), Vnezapnaya (Beklenmedik, Ani) ve Burnaya (Coşkun) gibi Yermolov'un kale ve kamplarının agresif kibirliliği de, terk edilmiş zafer takının kaderinin belirsizliği üzerine yapılan incelemeye benzer bir incelemeyi hak etmektedir. Kuzey Kafkasya'da ya da başka bir bölgede bulunan bazı Rus kaleleri ile yerleşim yerlerinin önemi, özellikle on sekizinci yüzyıl boyunca kolayca azımsanabilir. Kafkasya'nın ve Hazar'ın tamamı, bu yüzyılın sonuna kadar haydut çeteleriyle kaynamaktaydı. Rusya, Kuzey Kafkasya'ya ancak 1817 yılından sonra kararlı bir askeri harekât düzenleyebildi. Buna karşın, 1860'lı yıllara kadar "barış̧ıl" kabileler kendi istekleriyle taraf değiştiriyor, yalnızca dağlarda değil, dağ eteklerinde ve bozkırlardaki tehlikeli bölgelere seyahat ediyordu. Her sınır bölgesinde olduğu gibi burada da, varlığı neredeyse hiç anlaşılmayan bir devletten ziyade dost ve komşular, insanların geçimi ve güvenliği için daha önemliydi.

Bölgedeki tökezleyen askeri kuvvetiyle, Rusya on dokuzuncu yüzyıla dek demografik bir belirsizlikle karşı karşıya kalmıştı. Başka bir deyişle bölge ciddi bir "Rus" sınır bölgesi olmaktan çok uzaktı. Ruslar ancak on sekizinci yüzyıla gelindiğinde bu yerleşim merkezinde çoğunluğu sağlamıştı. Elbette bu yerleşim merkezi, Terek ve Kuban nehirlerinin ardında uzanan henüz işgal edilmemiş dağlık bölgeyi kapsamıyordu. Kızlyar ve Mozdok'ta bu tarihten sonra bile Ruslar çoğunlukta değildi. 1869 yılında toplam nüfusu yaklaşık 470 bin olan Terek Oblastı'nda yalnızca 123.036 Rus ve Ukraynalı yaşıyordu. ${ }^{30}$

Kuzey Kafkasya'daki Rus iskânı üç aşamaya ayrılabilir. Terek'in doğusunda 1560'lı yıllardan 1721'e kadar tarafsız Kazak köyleri 
kuruldu ve aynı bölgede ilk Rus kaleleri inşa edildi. 1721 yılında Terek Kazaklarının sorumluluğu dışişlerinden (Posolskiy prikaz) alınıp savaş bakanlığına verildi ve bu Kazaklar devlet görevlilerine dönüştürüldü. Rusya hükümeti çok sayıda Kazak'ı ve devlet görevlisini ancak ikinci aşamada (1722-1775) bölgede yeniden iskân etmeye başlayabildi. Terek boyunca birkaç yeni kale inşa edildi. Bunların içinde kalıcı olan ilk kale ise Kızlyar'dı. Üçüncü aşamada (1776-1860), askeri hat tamamlandı ve dağ içlerine doğru ilerletildi. Hat boyunca Kazaklar yeniden iskân ediliyor, Zaporojye Kazakları, Karadeniz Kazakları olarak anılmaya başlıyordu. Bu Kazaklara Kuban bölgesinde toprak verildi ve köylülerin yeniden iskânı ile kendiliğinden göç başladı. Rusların kitleler halinde bölgeye gelip yerleşmesi de yerel nüfus hareketlerinin yoğunlaşmaya başlamasıyla aynı zamanda oldu. Ermeni ve Gürcülerin göçleri, Osetlerin dağlardan dağ eteklerine inmesi, Nogayların bozkırdan Kuban Nehri'ne, Urallara ve Kırım ile Hazar bozkırlarına göçü ve son olarak da yaklaşık 700 bin Çerkes'in 1850 'li ve 1860 'lı yıllarda dışarıya göç etmesi bu göç hareketlerine dâhil edilebilir. ${ }^{31}$

Kalıcı Rus varlığı Terek boyunca tesis edilir edilmez yerel köylü ve esirler buraya yerleştirildi. Ancak bu durum çok ciddi diplomatik sonuçlara da yol açtı. Esirlerin içinde olduğu en ünlü olaylardan biri yerel kaçakların Rus himayesi altına alınmasıydı. Botanikçi Samuel Gotlib Gmelin 1774 yılında Hazar bölgesinde keşif gezisine çıktığı sırada Kaytag emiri (utsmi) Amir Hamza tarafından Dağıstan'da esir alındı. Amir Hamza'ya tabi olan yaklaşık 200 aile daha önce Rus hâkimiyeti olan bölgeye kaçmış ve koruma altına alınmıştı. Hamza, Gmelin'in salıverilmesi karşılığında ya bu ailelerin geri gönderilmesini ya da bunun yerine 30 bin rublelik fidye verilmesini talep etti. ${ }^{32}$ Kabardey prensleri ve soyluları 1740'lı yıllardan itibaren, kendi esirlerinin Rus yerleşim merkezlerine kaçmasını sürekli Rusya hükümetine şikâyet ediyordu. Mozdok kalesinin 1763 yılında bir Kabardey köyünün yakınlarına kurulmasının ardından yüzlerce Kabardeyin bu kaleye kaçarak Ruslara sığınması gerginliği daha da artırdı. 1764 yılında bir Kabardey heyeti St. Petersburg'a giderek kalenin yıkılmasını, Hıristiyan kaçaklar için tazminat ödenmesini ve diğer kaçakların da geri gönderilmesini talep etti. Elbette bu talep geri çevrildi. O sırada Mozdok'ta 200'den fazla din değiştirmiş 
Kabardey yaşıyordu. 1767 yılında, 10 bin kadar köylü Terek ve Malka nehirleri arasında kalan tahkim edilmiş bölgeye kaçtı. Ardından kaçış güzergâhı olarak kullanılmak üzere Terek Nehri'nin üzerine bir köprü inşa ettiler. Kızlyar kalesi komutanı tarafından Rus himayesi altına alınacakları sözü verilmesine karşın bu köylüler derebeyleriyle vergilerin düşürülmesi ve başka mülklere taşınma izni verilmesine dair bir anlaşma yaptı ve pek çoğu geri döndü. II. Katerina Kabardeylerin başka bir başvurusundan sonra 1771 yılında kaçak Kabardey esirlerinin geri gönderilmesine ve her Hıristiyan için 50 ruble ödenmesini kararlaştırdı. ${ }^{33}$ Bu karar Kabardey'i feodal toprağı olarak gören Osmanlı İmparatorluğu ile ilişkiyi kızıştırmamak ve din değiştiren çok sayıda Kabardey'in aslında Hıristiyanlıkla bir ilgisinin bulunmadığı düşünüldüğü için verilmişti.

Ruslar aynı zamanda dikkatlerini Osetlere çevirmeye de karar vermişti. Osetler "kararsız Hıristiyanlar" olarak biliniyordu ve geçmişte yaşadıkları yerlere misyonerler gönderilmişti. Osetlerin dağlardan vadilere yeniden iskânı, Mozdok (1763) ve Vladikavkaz (1784) kalelerinin kurulmasıyla başladı. Aslında başlangıçta Mozdok Osetlerin, Gürcülerin, Ermenilerin ve "başka Hıristiyan toplulukların" yeniden iskân edileceği, kendi kiliselerini inşa etme ve ibadetlerini yerine getirme özgürlüğüne sahip olacakları, Müslüman iskânının yasaklanacağı tahkim edilmiş Osetinskaya Kalesi adında bir yerleşim yeri olarak düşünülmüştü. Bu kalenin yerine Mozdok inşa edildi. Ancak hedef yine Osetlerin burada yeniden iskân edilmesiydi. Yermolov Kabardeyleri Gürcistan askeri yolunun geçtiği bölgeden sürmeye ve onların yerine Osetleri yerleştirmeye başlayınca 1820'li yıllarda yeniden iskân edilen Osetlerin sayısında artış görüldü. 1840'lı yıllara gelindiğinde 21 bin Oset Vladikavkaz ovasında yaşıyordu. ${ }^{34}$ Osetlerin çoğu özellikle Kazakların oluşturduğu Kazak Kardeşliği ve Dağ Kazakları Alayı gruplarının hizmetine girdi

Rus hükümeti on sekizinci ve on dokuzuncu yüzyıllarda, Kuzey Kafkasya'ya daha fazla sayıda Ermeni'yi çekme çabasını arttırdı. Karabağlı Ermeni Safar Vasilyev'e dut yetiştiriciliği için (ipekböceği tarımına yönelik) 1710 yılında Kızlyar bölgesinde tahsis edilen topraklar bir Ermeni'ye verilen ilk büyük toprak parçasıydı. Osmanlı ve İran topraklarından on sekizinci yüzyılda gelen çok sayıda Ermeni, Terek Nehri havzasında yeniden iskân edildi. Bazı Ermeniler de 
Kırımlılar ya da Nogaylar tarafından esir tutuldukları dağlardan kaçmıştı. Bu süreçte Kızlyar ve Mozdok'ta Ermeniler çoğunluğu oluşturuyordu. 1796 yılında Kızlyar'da 1000 Rus'a karşılık 2800 Ermeni yaşıyordu. 1789 yılında ise Mozdok nüfusunun yüzde 55,6'sı Ermeni ve Gürcü'ydü. Dağıstan'daki ve Hazar kıyılarındaki hanlıklarından gelen yaklaşık 3500 Ermeni daha, Kafkas askeri hattı boyunca 1797 yılında yeniden iskân edildi. Ermeniler ipek böcekçiliği ve bağcılıkla uğraşıyor, Kuzey Kafkasya'daki bölgesel ticaretin bel kemiğini oluşturuyordu. Başka bir büyük Ermeni grubu ise 1839 yılında Kuban'ın karşı yakasından getirilerek Çerkes dilinin bir ağzını konuşan (1859'da bile) ve onlara benzeyen bir topluluğun yaşadığı Armavir'e, Kazak hattının batı bölümü boyunca yerleştirildi. Kendilerini Ermeni olarak gören, Hıristiyanlık dinine mensup, Rus İmparatorluğuna tabi, etrafı Kazaklarla çevrili, dil, giyim-kuşam, mutfak ve gelenekleri bakımından Çerkes olan Armavir Ermenileri (Çerkesohaylar - ed.) sınır bölgesinin etnik olarak ne kadar karmaşık olabileceğini göstermektedir.

Kuzey Kafkasya'da geniş bir alana yayılmış, çok sayıdaki ilk "Rus" yerleşimcileri Kazaklardı. Kuzey Kafkasya'da Kazaklık tek bir etnik gruba ya da basit bir sınıf tanımına kolayca indirgenemeyeceğinden "Kazak" sözcüğünü tırnak işareti içinde kullanmak da mümkündür. On sekizinci yüzyıla gelindiğinde Rus devletinin Kuzey Kafkasya Kazaklarını askerlik, ajanlık ve inşaat gibi hizmetlerin zorunlu kılındığı kendi uyrukları olarak görmesi değişmeyen tek şeydi. Elbette bu durum her Kazak'ın zorunlu hizmetleri yerine getirdiği anlamına gelmiyor. Pek çok Kazak belirli hizmetleri yerine getirmemek için ayaklandı, eşkıya grupları oluşturdu ve askerden kaçarak dağa çıktı. Örneğin 1850'li yıllarda çiftlik soygunculuğu ve sığır hırsızlığı yapan, yalnızca Kazakları değil, aynı zamanda bozkır içlerinde yaşayan Kalmuk ve Nogayları da esir alan Kazak ve Çeçenlerden oluşan bir çete kurmuş, Naurskaya adlı Kazak köyünde yaşamış, iki kere dağa kaçıp İslam'ı seçmiş, Yakov Alpatov ne kadar "Kazak"tı?"

On altıncı ve on yedinci yüzyıllarda Terek boyunca ortaya çıkan Kazak toplulukları başka bölgelerden kaçıp gelen çok çeşitli insanlardan oluşuyordu. Bu insanlar göç eden ya da firari Kazaklar, Eski İnançlılar, Rus askerleri tarafından ele geçirilen tutsaklar ile kölelikten, cezadan ve kan davalarından kaçan Kafkas yerlileriydi. 
Gerçek Terek Kazakları 1721 yılında resmi olarak Rus hizmeti altına girene kadar bu bölgede yerleşimci, korsan olarak ve eşkıyalık yaparak bağımsız şekilde iki yüzyıldır yaşıyordu. Volga-Hazar-Terek güzergâhı, hem Kafkasya'daki yerleşim yerlerine ulaşım yolu, hem yağma, balıkçılık ve ticaret merkezi, hem de ana kültür merkezindeki ayaklanmalar için bir ulaşım yolu olarak her iki yönde kullanılıyordu. Köyler kuruluyor, terk ediliyor, köylüler öldürülüyor, esir alınıyor ya da başka yerleşimcilere katılıyordu. Terek Kazakları on yedinci ve on sekizinci yüzyıllarda meydana gelen ve Kazakların karıştığı başlıca ayaklanmalara katılmak için kitleler halinde kuzeye doğru gitti. Ardından bu mülteciler uzak kıyılara ve sık ormanlara doğru geri çekildi. O dönemde yaşanan belki de en ünlü isyan "Düzmece Petro" (Petruşka) isyanıydı. Düzmece Petro Terek'ten gelmiş, Bolotnikov'a katılmak için deniz yoluyla kuzeye gitmiş ve Volga boyunca eşkıyalık yapmıştı. Stenka Razin "illegal kariyeri"ne Hazar'da (ve Aşağı Volga'da) korsan olarak başladı. Terek'in Hazar Denizi'ne döküldüğü yerde bulunan Çeçen Adası'nı üslerinden biri olarak kullandı. Bazı Kazak korsanlar da on sekizinci yüzyılda Hazar Denizi'ni yağmalıyordu. 1737 gibi geç bir tarihte St. Petersburg'daki İran büyükelçiliği, Rus korsanların Hazar'da 70 kadar kayıkla Bakü'ye yakın bir adadaki üslerinden Hazar'da yağma yaptığını şikâyet etmişti. Pugaçev Terek'te de faaldi. 1772 yılında Terskoye Semeynoye Voysko'ya katılmış, Kazaklara ödenen ücretin yetersizliğinden yakınmış, Mozdok'ta tutuklanmış ve firar etmişti. ${ }^{37}$

Ancak Kafkasya yalnızca, kuzeyden gelen yağmacıların aktığı büyük Kazak denizinin en güney kıyılarından ibaret değildi. Kafkasya aynı zamanda kıyıya gelip yerleşen, yerli kadınlarla evlenen, dağda ve bozkırda yaşayan insanlarla omuz omuza savaşan ya da onlara karşı çıkan ve yerel topluluklarla birleşen Kazakların yaşadığı bölgeydi. Her ne kadar bürokratik ve keskin tarifler içerse de Yüzbaşı İvan JohannGustav Gerber'in 1728 yılında Hazar Denizi'nin batı kıyısında yaşayan farklı halkları betimleme şekli Kazak ve Kazak olmayanlar arasındaki çizginin ne denli karmaşık olduğunu gösterir. Soyu gerçek kaçak köylülere ve Kuzey Kafkasya dağlarında yaşayan ve yağmacılıkla geçinen Kazaklara dayanan Greben Kazakları da vardı. Gerber, Greben Kazaklarının, önceden kadınları ve çocuklarını kaçıran (çok büyük ihtimalle "Tatar" ve Kazaklar arasındaki evliliklerden olan) 
"Tatar" komşularının saldırılarına maruz kaldığını, ama günümüzde her iki grubun birlikte barış içinde yaşadığını söylemektedir. Terek garnizonundaki Terek Kazakları, Hıristiyanlığa geçen Don Kazakları ve Terek Tatarlarının bir birleşimiydi. Terek Tatarları önceden Müslümandı, "Nogayca" konuşurlar ve ("Nogaylar gibi") çadırlarda yaşarlardı. Yalnızca sığır yetiştiriciliğiyle uğraşmaz, aynı zamanda balıkçııı da yaparlardı. Dağlarda yaşayan "Tatarlara" tuzlu ve kurutulmuş balık satarlardı. Bazı kaynaklara göre ise "Terek Tatarları" Terek Nehri'nin ağzında balıkçılıkla uğraşan Kazaklar ve yerli halk için kullanılan bir isimdi. Bu insanlara on sekizinci yüzyılda "Terek Nogayları" da deniyordu. Hıristiyan ve Kazak olan Stavropol Tatarları Rusça konuşurdu. Dağıstanlı ve Andrey (Endirey) Kumuklarının yaşadığı köy "hırsızlık yaparak geçinen kaçak Ruslar ve Kazaklar" tarafından kuruldu ve bu grup "hırsızlığa benzer işler yapan Tatarlarla" birleşti. ${ }^{38}$

Kuzey Kafkasya'daki Kazak unsurların etnik çeşitliliği, on sekizinci ve on dokuzuncu yüzyılda Rusya'nın bölgeye yönelik ilgisinin artmasıyla gittikçe daha da karmaşık hale geldi. İnşa edilen her yeni kaleyle birlikte iç bölgelerden gelen Don, Volga, Hoper ve Yaitsk Kazakları yeniden iskân ediliyordu. Ermeniler, Gürcüler ve Kuzey Kafkasya'da yaşayan Rus olmayan diğer halklar sürekli, Kazak alaylarına kabul ediliyordu. Çeçenler, Kabardeyler, Osetler ve yerli halklara mensup başka kişiler hâlihazırda var olan Kazak alaylarına katılıyor ya da Dağlı-Mozdok Alayı, Dağ Kazakları Alayı ve Kızlyar düzensiz birlikleri gibi birliklere katılıp kendi alaylarını oluşturuyordu. Çoğu Müslüman din değiştirip, Ortodoksluğa geçmiş olsa da DağlıMozdok alayının Müslüman askerleri de vardı. 1858 gibi geç bir tarihte bile Kafkas askeri hattındaki Kazakların yüzde onu Müslümandı. Yeniden iskân edilen devlet köylüleri, kaçak serfler ve emekli askerler de kitleler halinde Kazakların hizmetine giriyordu. 1832 ve 1833 yılları arasında devlet köylülerinin yaşadığı otuzu aşkın yerleşim yeri Kazak köyü olarak kabul edildi. Çoğunluktaki Zaporojye Kazakları Karadeniz Kazakları olarak düzenlendi. Bu gruba 1792 yılında Kuban Nehri boyunca toprak verildi ve Osmanlı-Rus Savaşı'nda savaşan, ancak Zaporojye Kazağı olmayan binlerce Kazak da aynı bölgeye yerleştirildi. Bir tarihçiye göre gerçek Karadeniz Kazaklarının yalnızca yüzde otuzu gerçek Zaporojye Kazağıydı. Geriye 
kalan sayının yüzde kırkını onlarla birlikte savaşmış gönüllüler ile yüzde otuzunu onlarla birlikte yeni sınır bölgesine yerleşmiş Lehler, Ruslar, Moldovalılar ve diğer halklar oluşturuyordu. Sonraki 60 yıl boyunca 80 binden fazla Kazak ile Ukrayna'dan gelen köylüler buraya gönderildi. ${ }^{39}$ Bu sayıya, göç eden kolonistlere yasadışı şekilde katılmış olan ve Kazak oblastlarında yaşayan ancak Kazak olmayan binlerce kişi de (inogorodnıy)eklendi.

Bununla birlikte, Kuzey Kafkasya'ya dikkat çeken sayıda Rus ve Ukrayna köylüsü de kaçmıştı. Bu köylüler, devlet köylülerinin ya da Kazakların yeniden iskân edildikleri yerleşim yerlerine katılmış ya da kendi yerleşim yerlerini kurmuştu. Bu yerleşim yerleri bazen onlarca yıl tespit edilemiyordu. Halk geleneğine göre, Kuzey Kafkasya'da bulunan pek çok köy başlangıçta kaçak köylülerin oluşturduğu çetelerin saklanma yeriydi. Örneğin 1750 'lerde bölgedeki sık ormana yerleşen ve eşkıyalık yapmak için komşu "Tatar" köylerine katılan kaçak serf Pyotr Burlak'ın Kalaus Nehri'ndeki Petrovskoye'yi kurduğu söylenir. Daha sonra pek çok kaçak serf, aileleriyle birlikte Burlak'a katılmış ve ormanın derinliklerinde bu Rus köyü ortaya çıkmıştı. Buyvola Nehri'nin sağ kıyısındaki Burlatskoye Vadisi'nde büyük intimalle askerlik görevinden ve derebeylerinden kaçıp gelen, soygun ve yağma ile geçimlerini sağlayan kaçak köylüler yaşıyordu. ${ }^{40}$

Kuzey Kafkasya'ya kaçan köylü sayısı, devlet köylülerinin ve Kazakların devlet tarafından bölgede yeniden iskân edilmesinin ardından güney bölgelerde vergiden ve yükümlülüklerden muaf olunduğuna dair söylentiler ortaya çııınca $1820^{\prime}$ li yıllarda artış gösterdi. I. Nikolay, 1826 yılının mayıs ayında özel bir ferman yayınlayarak köylü ve serflerin Kafkasya'da özgür olduğuna dair söylentilerin yanlış olduğunu ve bu bölgeye kaçanların hukukun izin verdiği ölçüde cezalandırılacağını açıkladı. Bu ferman hedeflediği şeyi gerçekleştiremedi. Binlerce köylü sonraki otuz yıl boyunca Kuzey Kafkasya'ya geldi. Bölgedeki nüfusun artmasına ve tarımı geliştirmeye ihtiyaç duyan yerel yöneticiler ise yeni gelen köylülerin statüsünü görmezden geldi. Bazen de köylüler buraya söylentiler yüzünden değil de başka amaçlarla geliyordu. Saratov valisi 1832 yılında kaçakların para karşılığında başka kişileri hizmetlerini satın almak için bölgeye ve Don Kazaklarının yaşadığı yerlere geri döndüğünü bildirmişti. Aynı şey Voronej'de ve Yekaterinoslav'da da 
görülüyordu. Kimi zaman silahlı çeteler mülklerini ve ailelerini geri almak için geri dönüyordu. Karadeniz Kazakları da, kaçakları kiralayıp iş̧̧i kıtlığı çekilen yerlerde çalıştırmak amacıyla bölgeye aracılar gönderiyordu. ${ }^{41}$

1837 yılında köylüler Anapa bölgesine kaçmaya başlamıştı. Söylentilere göre burada kaçaklara sığınacak yer ve Kazak olarak hizmete alınma olanağı veriliyordu. Başka bir söylentiye göre ise geri dönmelerine ve aile birleşmesine izin veren belgeler burada temin ediliyordu. Böylece binlerce insan bu bölgeye geldi. Bazı köylülerin sahte pasaportları bile vardı ve at arabalarıyla alenen göç ediyordu. Haydamak olarak yaşayan, balıkçılık ve soygunculukla uğraşan ve "Zaporojye Kazakları gibi her zaman tüfek, altıpatlar ve mızrak kuşanıp dolaşan" kaçaklardan oluşan çetelerin Temryuk eteklerinde görüldüğüne dair bilgiler de mevcuttur. Belki de vahşi özgürlüğün yaşandığı artık çok geride kalmış o eski yaşamın hayali bazı köylüleri kendine çekiyordu. Ancak köylüleri buraya çeken daha önemli şey kaçakların Kazaklar tarafından kabul görmesiydi. Kazaklar ya kaçakları hemen hizmetlerine alıyor ya da onlara çiftliklerinde sığınacak yer veriyordu. Ayrıca Kazakların bu insanları, işgücü sıkıntısı yüzünden kendi balıkçı ekiplerine aldığı da oluyordu. ${ }^{42}$

Kuzey Kafkasya toplumunun göreli yerleşim özgürlüğü dışındaki en büyük özelliği belki de işgücü azlığıydı. Rusya'nın geri kalanında en çok görülen, serflerin yaşadığı bir köy ile derebeyinin kaldığı bir malikâneden oluşan köyler burada en nadir görülen yerleşim şekliydi. 1857 yılında serfler Kuzey Kafkasya (Stavropol ili ve Terek ve Kuban oblastları) nüfusunun yüzde üçünden daha az bir kısmını oluşturuyordu. Çok az yerleşimin olduğu Arhangelsk ve Sibirya dışında bu bölge Rusya İmparatorluğu'nda serf oranının en düşük olduğu bölgeydi. ${ }^{43}$

İşgücü açığı tarla ve bahçelerinde çalıştırmak için çok sayıda işçi kiralayan Kazakların ve devlet köylülerinin toplumsal dünyasını da renklendiriyordu. 1850 'li yılların yaz aylarında Kafkas askeri hattındaki Kazaklar dört bini aşkın, Karadeniz Kazakları ise 15 bini aşkın sayıda çiftlik iş̧̧isi kiralıyordu. Devlet köylüleri de yıllık olarak binlerce iş̧̧i kiralıyor ve bu iş̧̧ilerin büyük çoğunluğunu çiftliklerde çalıştırıyordu. Bu mevsimlik işçilerin bir kısmı Rusya içlerinden gelen köylüler, bir kısmı da yerel halktandı. On dokuzuncu yüzyılın ortalarında, dağlardan 
gelen 20-25 bin mevsimlik iş̧̧i ilkbahardan sonbahara kadar Kızlyar'da yaşıyordu. Sayı o kadar fazlaydı ki 1842 yılında "mukim olmayan barış̧ıl Dağılara" yardım etmek için özel ofisler oluşturuldu. 1850'li yıllar boyunca 15 bin Nogay, Kızlyar uyezdinde toprak sahipleri ve Kazaklar için çalışıyordu. ${ }^{44}$ Kasabalarda ve Kazak köylerinde yerel halkın sayısı özellikle pazarların kurulduğu günlerde daha da artıyordu.

Esas olarak kasabalar, etnik gruplar arası etkileşimin görüldüğü başlıca yerlerdi. Ticaret için ve mevsimlik iş̧̧i olarak her köşeden Kuzey Kafkasya şehirlerine gelen yerel halk ile kalıcı olarak burada yaşayan insanların bulunduğu bu bölgesel ticaret merkezleri canlı ve çok etnikli bir karakter kazanıyordu. Ancak Kuzey Kafkasya'daki tüm Rus kasabaları bu denli eşit derecede çeşitlilik içermiyordu. Kızlyar ve Mozdok gibi eski kale kasabaları yerel ticaretin, etnik çeşitliliğin ve Rus-yerli etkileşiminin merkeziydi. Karadeniz Kazaklarının başkenti Yekaterinodar, çok büyük ölçüde Kazak nüfusuna sahip olarak kaldı. Ancak pazarların kurulduğu günlerde ve karnaval günlerinde Kuban'ın ötesinde yaşayan binlerce insan şehre akın ederdi. 1843 yılında Yekaterinodar şehrini ziyaret eden Moritz Wagner buradaki Çerkeslerle ilgili şunları yazmıştı: "Bundan birkaç gün önce ülkeyi işgal etmiş ve belki yakıp yıkmış ve insan öldürmüş bu kişilerin, şimdi Kazak grupları arasında sakince dolaştığını görmek çok garip." Kuzey Kafkasya'nın on dokuzuncu yüzyılda en hızlı büyüyen kasabası Stavrapol bir yönetim merkezi ve Kazak/devlet köylüsü kasabasıydı. Bu yüzyılın ortasına kadar Vladikavkaz, çevresinde Osetlerin yaşadığı yerleşim merkezlerinin olduğu askeri bir kasaba olarak kaldı. ${ }^{45}$

Kafkas askeri hattındaki kasabaların ve Kazak köylerinin sınırlarında, yerli halkın yaşadığı çeşitli yerleşim yerleri ile "barışçı" denilen Dağlıların köyleri bulunuyordu. Bu kabileler Rusya İmparatorluğu'na sözde bağlılık yemini etmiş ve Rus hattında atlı baskınlara son vermişlerdi. Ancak askeri varlığın akışkanlığına bağlı olarak, barış̧ıl kabileler kolayca taraf değiştirebiliyor ve baskıncılara katılabiliyordu. Sınır komşusu olan yerleşim yerleri ile hat üzerindeki kale kasabaları ve Kazak köyleri sürekli bir etkileşim halindeydi. Ancak tarafların her birinin aklında diğeriyle ilgili şüpheler vardı. Potto'ya göre "Sunja ve Terek nehirleri" arasında yaşayan "barışçıl Çeçenler", sınır komşusu yerleşim yerleri arasındaki "en kötü ve tehlikeli" gruptu: "Barış̧ıl köyler, Kafkasya'da yaşayan her kabilenin eşkıyası için uğrak 
noktalardı. Çeteler, askeri hatta akın yapmadan önce burada kalırdı. Her türlü suçlu bu köylerde sıcak karşılanırdı. Son olarak hiçbir yerde, bu köylerde olduğu kadar Rus kaçak yoktu." Kuban Nehri'nin sol yakasında yaşayan Çerkeslerin karşı karşıya kaldığı durumun farkında olan Wagner ise bu insanların halinden anlayışla bahsetmektedir: "Ruslar ve Rusların düşmanları arasına sıkışıp kalmış olan bu halk tüm gücüyle tarafsız kalmaya çalışır. Her iki tarafla dostane ilişkiler kurar, bazen Ruslar için savaşır, bazen de komşularıyla birlikte Ruslara karşı mücadele eder. Ayrıca bu halk her iki taraf için de gözcülük ve casusluk yapar." ${ }^{46}$ Sürekli taraf değiştiren bu güvenilmez topluluk, Kuzey Kafkasya'da Rus devleti için başlıca sorun kaynağıydı. Bu yüzden komutanlar ayrım gözetmeyen karşı saldıılar yoluyla durumu kontrol altına almaya çalışıyordu.

Askerden kaçan Ruslar ve diğer etnik unsurlar güvenilmez bir başka gruptu. Bu grubun sayısı büyük ihtimalle hiçbir zaman çok fazla değildi. Ancak sınır bölgesinin etnik akışkanlığı her zaman bilinen bir gerçektir. Bu durum yerel yetkililer arasında Dağılıarla asıl kimin savaştığına dair ciddi kaygılara yol açıyordu. On sekizinci yüzyıldaki yerel komutanlar, Dağlı kabilelere etnik ve kültürel açıdan yakınlıkları nedeniyle Terek Kazaklarından şüpheleniyordu. Ordu, 1722 yılında Svyatoy Krest kurulduktan sonra Greben Kazaklarını (Terek'in ilk Kazakları) buraya yerleştirmek istedi. Ancak, kaçarak Kuban'ın karşı tarafına geçmelerinden korkulduğundan Greben Kazaklarının yeri değiştirilmedi. Daha sonra 1770'lerde Greben Kazaklarının, Bulavin isyanından kaçıp aşağı Kuban bölgesine yerleşen, Kabardeylerle birlikte Rus yerleşim yerlerine akınlar düzenleyen ve $1768-1774$ yılları arasındaki Osmanlı-Rus Savaşı'nda Türklerin safında savaşan Nekrasov Kazaklarıyla gizli bir anlaşma yaptığı şüpheleri ortaya çıktı. 1774 yılında General De Medem, Greben Kazaklarının, ancak büyük bir dikkatle hizmete alınabileceği emrini verdi. ${ }^{47}$ On sekizinci yüzyıl boyunca, sorunların ortaya çıktığı dönemlerde çatışma intimali nedeniyle kalelerin, yerel halkla teması zaman zaman yasaklanıyordu.

1817 yılından sonra düzenlenen yoğun askeri harekâtlar sırasında Rusya, mütemadiyen firari askerlerle uğraştı. Belli dönemlerde, Rus asker kaçaklarının çeşitli köylerden geri gönderilmesi talep ediliyordu. 1842 yılında I. Nikolay yerel komutanlara, bu köylere rüşvet olarak tuz verilmesini emretti. 1845 
yılında, Vorontsov tarafından geri dönecek asker kaçakları için genel af çıkarılacağına dair resmi bir duyuru yayınlandı: "Başkomutan, asker kaçaklarının, bundan böyle heteredokslar içinde kaçak olarak yaşamak istemeyeceğini ve çarın af ve merhametine sığınmak için acele edeceğini umut etmektedir." ${ }^{48}$

Ancak çoğu asker kaçağı geri dönmedi ve tanıklara göre durumları hiç de kötü değildi. Ele geçirilen bir Kazak, Şamil'in Vedeno köyünde 300 kaçak Rus askeri olduğunu, bu askerlerin toplarla ilgilendiğini, Çeçenlerle evlendiğini, "Çerkes kıyafetleri" giydiğini ve "yeteri kadar iyi" bir yaşam sürdüğünü itiraf etmişti. Yüzbaşı A.I. Runovski'nin raporlarına göre İslam'ı seçen, yerli kadınlarla evlenip mutlu bir aile hayatı kuran çok sayıda kaçak Rus askeri vardı. Runovski'ye göre kaçak Ruslarla evlenmek için baba ocağını terk eden pek çok kadın görülüyordu. Çünkü Ruslar eşlerine yerli erkeklerin davrandığından daha iyi davranıyordu. Bununla birlikte kaçaklar aynı zamanda Şamil'in özel koruması altındaydı. Şamil, kaçakları yeni komşularının olağan baskısından korumak için sıkı önlemler alıyordu. Söylentilere bakılırsa, 400-600 Rus askeri Şamil'le birlikte Dargo'da yaşıyordu. Şamil'in kaçak Rus askerleri tarafından inşa edilen Avrupa tarzı bir evde yaşadığı, Rus ve Leh birlikleri üzerine inşa edilmiş ve içinde "tüm halklardan" askerlerin olduğu 4 bin kişilik bir birliği komuta ettiği, Şamil'in selefi Hamza Bek'in de sürekli Rus muhafızlarca korunduğuna dair söylentiler vardı. Hatta 1837 yılındaki savaşta hayatını kaybettikten sonra naaşı hiçbir zaman bulunamayan yazar Aleksandr Bestujev-Marlinski'nin de hala hayatta olduğu ve Şamil'in yanında savaştığı konuşuluyordu. ${ }^{49}$ Aslında önemli olan bu söylentilerin gerçek olup olmadığı değil, yayılmış olmasıdır. Bu söylentilerin varlığı bile sınır bölgesinde muazzam etnik belirsizliğin olduğunu kanıtlamaktadır. Unsurlar arası evlilikler, etkileşimler, din değiştirmeler, kültürel etkileşimler ve firarlar nedeniyle Kafkasya'da kimin kim olduğunu söylemek zaman zaman zorlaşıyordu. Puşkin'in Kazbek'ten Tiflis'e dönüş yolunda "gösterişli bir Doğulu"dan çok Avrupalı bir beyefendi olduğu ortaya çıkan İranlı saray şairiyle tanıştıktan sonra söylediği gibi, Kafkasya'da birini yalnızca "başındaki papağa ve tırnaklarındaki kınaya bakarak yargılamamak" en doğrusuydu. ${ }^{50}$ 
Ruslar Kuzey Kafkasya sınır bölgesinin bu belirsizliğini çözmek için pek çok şey denedi. Tarihçiler Yermolov'un Rus hatlarına yapılan saldırılardan sonra hedef gözetmeksizin dağ köylerini yok etmesi gibi bir takım sert askeri uygulamalar üzerine oldukça iyi çalışmalar yapmıştır. Yermolov'un toplarla desteklenen yıldırım birlikleri Kabardey'de köyden köye dolaşarak halkın boyun eğmesini, baskınlarını ve göçün durdurulmasını talep etti. Köylerin gelişigüzel yok edilmesi, bahçelerin ateşe verilmesi, sığırların çalınması, ormanların kesimi ve insanların zorla yeniden iskânı bu belirsizliğin giderilmesi için gösterilen nafile bir çaba olarak kalmıştır. Bu durum "biz" ve "onlar" arasındaki hatları kalınlaştırmıştır. Gerçekte de tüm bu uygulamalar hatların belirginleşmesine neden olmuştur. Yermolov'un sisteminin Kuzey Kafkasya'da süregiden savaşın şiddetinin artmasına ve Şamil'in Rusları sürmek için dört bir yana dağılmış Dağlıları bir araya getirme başarısına katkı sağladığı söylenebilir. Ancak ittifak kurmaya ve etnik kimlikleri aydınlatmaya yarayan başka teknikler de vardı. Bölgedeki insan kaleydoskopuna uygulanan yaratıcı etnografya, tutsaklıkla ilgili hikâyeler vee kahramanlık efsanelerinin kullanımı bunlardan birkaçıydı. Örneğin esir alma ve fidye her iki tarafta da yüzyıllardır uygulanan sıradan eylemlerdi. Ancak on dokuzuncu yüzyılda bu durum yaygınlaştı ve askeri hattı geçmek için kullanılan başlıca yöntem olarak halka tanıtıldı. Ayrıca esir ve fidye Kafkasyalılara atfedilen terör ve işkence eylemleri olarak stereotipleştirildi. Aynı dönemde Rusların bu eylemleri yapması ise medeni olarak görülüyordu.

Bölgede çok sayıda kahramanlık efsanesi de ortaya çıktı: Böyle konuların, sınır bölgesinin sağlamlaştırılması süreci için ne kadar önemli olduğunu göstermek için bu kahramanlık efsanelerinden birini anlatacağım. Rus sınır bölgesinin Kuzey Kafkasya'daki ilk kahramanlık efsanelerinden biri 11 Haziran 1774 yılında Naurskaya Kazak köyünde yapılan bir savaşta ortaya çıkmıştır. General De Medem tarafından yazılan bir rapora göre on bin Kabardey, Volga Kazaklarının yeniden iskân edildiği yeni kurulmuş bu köye saldırdı. Ancak tırpanlarla savaşıp saldırganların başlarından aşağı sıcak su döken kadınların da içinde bulunduğu 800 köylü tarafından geri püskürtüldü. Daha da önemlisi, bu baskın, ittifakların tehdit altında olup çözüldüğü kargaşa bağlamında meydana geldi. Ölü 
Kabardeylerin arasında, o tarihten üç yıl önce St. Petersburg'da yüzbaşı rütbesi alıp yıllık 150 rublelik maaşın da sahibi olan Korgok Tatarhanov'un cesedi bulundu. Saldırıdan sadece birkaç gün önce Nekrasov Kazakları, Greben Kazaklarını Rusya ile kurdukları ittifaktan vazgeçirmek için bölgeyi ziyaret etmişti. Pugaçev de bundan iki yıl önce Naurskaya'ya gelmiş ve aldıkları ücretin yetersiz olduğuna dair yeni gelenlere propaganda yapmıştı. Ardından Naurskaya köyü ve iki Kazak köyü tarafından, durumlarını protesto etmesi için St. Petersburg'a gitmekle görevlendirilmişti. ${ }^{51}$

Belirsiz ittifakların olduğu bir bağlamda yapılan muazzam bir savunma, zamanla Kazakların gerçek "Rusluklarına" dair bir hikâyeye dönüştü. 1862 yılında N. F. Samarin Naurskaya'yı ziyaret etti ve ardından hikâye tamamen değişti: Kabardeylerin sayısı 14 bine çıktı, Kazakların sayısı ise 200'e indi. Savaşa kalenin surlarından taş atan çocuklar katıldı. Kadınlar tırpan ve oraklarla dövüştü. Bu kadın kahramanlardan biri üç Kabardeyin kellesini aldı. Saldırganların başlarından aşağı sadece sıcak su değil, Rus yemekleri, kabak çorbası da döktüler. Samarin'e göre, kuşatma 11 Haziran Aziz Bartholomev ve Barnabas günü sona erdi. Böylelikle Kazaklar azizlerin onuruna bir kilise inşa etti. Efsaneye göre bu azizler beyazlara bürünmüş bir şekilde beyaz atlarının sırtında aniden düşman çadırlarının arasında ortaya çıkmış ve askerleri geri çekilmeleri için korkutmuş. 11 Haziran günü Naurskaya'da bayram ilan edildi: Askeri geçitler, "savaş oyunları" ve sokak eğlenceleri (gulyanye) için tüm alaylardan Kazaklar bu bayramda bir araya geliyordu. Savaş ayrıca günlük dildeki ifadelere de girdi. Naurskaya'da yaşayan Kazaklar, Kabardeylerle karşılaştıklarında "Kardeşim, sen Naurskaya'da kabak çorbası içmedin mi?" diye soruyordu. Bu mağlubiyetin Kabardeyleri de derinden etkileyen bir anlamı vardı. Pek çok kanlı savaş Kabardeylerin bu şekilde kışkırtılması sonucunda yaşanıyordu. ${ }^{52}$ Nihayetinde Naurskaya'da yaşanan savaş sadece bir Kazak hikâyesi olarak kalmadı, aynı zamanda Naurskaya Kazaklarının günlük hayatlarına da kök saldı. Efsanenin ortaya çıkışında Kazakların mı yoksa Kazaklarla ilgili efsaneler yazanların mı daha önemli olduğunu belirlemek imkânsız olsa da, hikâyenin Ruslaşması pek çok anlamı olan bir olayı basitleştirdi ve bu olay Rus devletinin çıkarlarına yönelik kullanıldı. 
İşte bu, üzerine yapılacak çalışmaların devam edeceği, etnik çeşitlilik, nüfus hareketleri, değişen ittifaklar, kültür paylaşımı, karşıııkı ekonomik bağlıııklar ve yerleşimcilerin de yerliler kadar bağlı olduğu bir ekoloji tarafından yaratılmış bir Rus sınır bölgesidir. Elbette bu bölge, sınırların olmadığı bir bölge değildi. Bölgede, siyasetin, savaşın, şiddetin, coğrafyanın neden olduğu pek çok sınır vardı. Etnik kışkırtmalar gibi günlük hayatın doğurduğu sınırlar da bunlardan biriydi. Ancak son tahlilde, durum yalnızca beyaz ya da siyah atların sırtında cereyan eden savaştan daha karmaşıktı.

\section{DIPNOTLAR}

${ }^{1}$ F. von-Kliman, "Voyna na vostoçnom Kavkaze s 1824 po 1834 g. v svyazi s myuridizmom," Kavkazski sbornik, 15 (1894): 524.

2 John F. Baddeley, The Russian Conquest of the Caucasus (Londra: Longmans, Green and Co., 1908); Marie Bennigsen Broxup, ed., The North Caucasus Barrier (New York: St. Martin's Press, 1992); Moshe Gammer, Muslim Resistance to the Tsar: Shamil and the Conquest of Chechnia and Daghestan (Portland: Frank Cass, 1994). Bkz. W. E. D. Allen ve Paul Muratoff, Caucasian Battlefields (New York: Cambridge University Press, 1953). Rus edebiyatında ve toplumunda Kafkas imgesi için, bölgeyi sınır bölgesinden çok merkeze konumlandıran şu eserlere bakmakta da fayda var: Uwe Halbach, "Die Bergvolker (gorcy) als Gegner und Opfer: Der Kaukasus in der Wahrnehmung Russlands," Kleine Volker in der Geschichte Osteuropas' Kleine Volker in der Geschichte Osteuropas, ed. Manfred Alexander, Frank Kampfer ve Andreas Kappeler (Stuttgart: Franz Steiner, 1991), 52-65; Thomas M. Barrett, "The Remaking of the Lion of Dagestan: Shamil in Captivity," Russian Review 53 (Temmuz 1994): 353-66; Susan Layton, "The Creation of an Imaginative Caucasian Geography," Slavic Review 45 (Güz 1986): 470-85.

3 "Dağlılar" ("gortsı") terimini o dönemdeki Rusların kullandığı anlamıyla, Kuzey Kafkasya'daki dağlarda ve dağ eteklerinde yaşayan insanları tanımlamak için kullanıyorum. Bu terim, batıda yaşayan Çerkeslerden, doğuda Dağıstan'da yaşayan pek çok halka kadar olağanüstü sayıdaki etnik grubu kapsamaktaydı. Bu makalede yapabildiğim yerlerde daha kesin etnik isimler kullanacağım. Elbette Kuzey Kafkasya'da yaşayan insanlar arasında bozkır göçebeleri de vardı. Nogaylar bunun örneğidir. Bununla birlikte Kuzey Kafkasya'da yaşayan Ukraynalılar Rus olarak sınıflandırılıyordu. Makale 
boyunca özellikle Rusları ve Ukraynalıları belirtmek için "Rus" sözcüğünü kullanmak zorundayım.

${ }^{4}$ Rus ve Kafkas ilişkilerini inceleyen en önde gelen askeri tarihçi büyük ihtimalle Vasili A. Potto'ydu. Bkz. Potto V. A. Kavkazskaya voyna v otdelnıh oçerkah, epizodah, legendah i biografiyah, 5. cilt. (St. Petersburg: Tipografiya R. Golike, 1885-1891) ve Utverjdeniye russkogo vladıçestva na Kavkaze, 3 cilt. (Tiflis: Tipografiya la. K. Libermana, 1901-1904).

${ }^{5}$ Örneğin, S.K. Buşuyev, ed., İstoriya Severo-Osetinskoy ASSR (Moskova: Izd. Akademiy nauk SSSR, 1959): G.D. Daniyalov, ed., Istoriya Dagestana, 5 cilt. (Moskova: Nauka, 1967-1969); T. H. Kumıkov, ed., İstoriya KabardinoBalkarskoy ASSR s drevnıh vremen do naşih dney, 2 cilt. (Moskova: Nauka, 1967); N.A. Smirnov, Politika Rossii na Kavkaze XVI-XVII vv. (Moskova: İzdatelstvo sotsialno-ekonomiçeskoy literaturı, 1958); N.S. Kinyapina, M.M. Bliyev ve V.V. Degoyev, Kavkaz i Srednaya Aziya vo vneşney politike Rossii: Vtoraya polovina XVIII-80e godı XIXV. (Moskova: Izdatelstvo Moskovskogo universiteta, 1984).

${ }^{6}$ Sovyet tarihiyle ilgili çalışmalar yapan önemli tarihçilerden biri B.B. Pyotrovski'dir; ed., İstoriya narodov Severnogo Kavkaza s drevneyşih vremen do kontsa XVIII v. (Moskova: Nauka, 1988); ve A. L. Naroçnitski, ed., Istoriya narodov Severnogo Kavkaza (konets XVIII v-1917 g.) (Moskova: Nauka, 1988). Konu hakkında iki bibliyografya M. M. Myansarov'a aittir, Bibliographia Caucasica et Trans- caucasica (St. Petersburg: Tipografiya O. I. Baksta i Gogenfelden i Komp., 1874-76); Moshe Gammer, "Shamil and the Murid Movement, 1830-1859: An Attempt at a Comprehensive Bibliography," Central Asian Survey 10, no. 1/2 (1991): 189-247.

7 Joseph L. Wieczynski, The Russian Frontier (Charlottesville: University Press of Virginia, 1976); George V. Lantzeff ve Richard A. Pierce, Eastward to Empire: Exploration and Conquest on the Russian Open Frontier to 1750 (Montreal: McGill-Queen's University Press, 1973); Roger Dow, "Prostor: A Geopolitical Study of Russia and the United States," Russian Review 1, no. 1 (Kasım 1941): 7-8. Denis Shaw'un yeni yayınlanan bir makalesi bile Turner'ın sınır bölgesi yaklaşımından yararlanır. Bkz. Judith Pallot ve Denis J.P. Shaw, Landscape and Settlement in Romanov Russia, 1613-1917 (Oxford: Clarendon Press, 1990), 13-32.

${ }^{8}$ Donald W. Treadgold, "Russian Expansion in the Light of Turner's Study of the American Frontier," Agricultural History 26, no. 4 (Ekim1952): 14752; A. Lobanov-Rostovsky, "Russian Expansion in the Far East in the Light of the Turner Hypothesis," The Frontier in Perspective, ed. Walker D. Wyman ve Clifton B. Kroeber (Madison: University of Wisconsin Press, 1957), 79-94. Aşağı Volga'daki yoğun iskân ancak 1780'li yıllardan sonra başladı. Bkz. V.M. 
Kabuzan, Narodı Rossii v XVIII veke. Çislennost i etniçeski sostav (Moskova: Nauka, 1990), 90.

9 Donald W. Treadgold, The Great Siberian Migration (Princeton: Princeton University Press, 1957); Raymond Fisher, The Russian Fur Trade, 1550-1700 (Berkeley: University of California Press, 1943); Terrence E. Armstrong, Russian Settlement in the North (New York: Cambridge University Press, 1965); William H. McNeill, Europe's Steppe Frontier, 15001800 (Chicago: University of Chicago Press, 1964); E. I. Drujinina, Severnoye priçernomorye v 1775-1780 gg. (Moskova: Izd. Akademiy nauk SSSR, 1959): N. D. Polonska-Vasılenko, "The Settlement of the Southern Ukraine (17501775)," The Annals of the Ukrainian Academy of Arts and Sciences in the U.S. 4-5 (Yaz-Güz 1953); D. I. Bagaley, Materialı dlya istorii kolonizatsii i bıta stepnoy okraynı Moskovskogo gosudarstva v XVI-XVII stoletii, 2 cilt. (Harkov: Tipografiya K.P. Schasni, 1890). Sibirya'da yer almayan bir frontier ile ilgili az sayıdaki eserden biri de Michael Khodarkovski'ye aittir: Where Two Worlds Met: The Russian State and the Kalmyk Nomads, 1600-1771 (Ithaca: Cornell University Press, 1992). Kitap çoğunlukla Kalmukları ve Rus devletiyle ilişkilerini irdelese de yazar Volga boyunca yürütülen ve Kalmuklarla askeri temasa neden olan Rus kolonizasyonunu da kısaca incelemektedir (sy. 30835) Diğer iki istisna ise Boris Nolde, La Formation de l'Empire russe, 2 cilt. (Paris: Institut d'Etudes slaves, 1952-53) ve Andreas Kappeler, Russlands erste Nationalitäten: Das Zarenreich und die Völker der Mittleren Wolga vom 16. bis 19 Jahrhundert (Cologne: Bohlau, 1982).

10 Alan Fisher, The Crimean Tatars (Stanford: Hoover Institution Press, 1978); Azade-Ayşe Rorlich, The Volga Tatars (Stanford: Hoover Institution Press, 1986); Zenon H. Kohut, Russian Centralism and Ukrainian Autonomy (Cambridge: Harvard University Press for the Harvard Ukrainian Research Institute, 1988); James Forsyth, A History of the Peoples of Siberia: Russia's North Asian Colony, 1581-1990 (New York: Cambridge University Press, 1992).

11 Amerikan sınır bölgesi tarihiyle ilgili yakın zamandaki çalışmalar üzerine yapılan incelemeler için bkz. William Cronon, George Miles ve Jay Gitlin, ed., Under an Open Sky: Rethinking America's Western Past (New York: W. W. Norton, 1992); Patricia Nelson Limerick, Clyde A. Milner II ve Charles E. Rankin, ed., Trails: Towards a New Western History (Lawrence: University of Kansas Press, 1991).

12 Cronon, Miles and Gitlin, Under an Open Sky, 12. Yazarlar, bu makalede "Yer Değiştiren Türler" terimini kullanmaktadır.

${ }^{13}$ Çevre tarihi üzerine yazılan başyapıtların çoğunun sınır bölgeleriyle ilgilenmesi tesadüf değildir. Bkz. Carl Ortwin Sauer, The Early Spanish Main 
(Berkeley: University of California Press, 1966); Alfred W. Crosby, The Columbian Exchange (Westport: Greenwood, 1972); ve William Cronon, Changes in the Land (New York: Hill and Wang, 1983).

${ }^{14}$ Y.T. Pyshnova, "Historical-Geographic Aspects of the Development and Settlement of the Black Sea Coast of the Caucasus,"tlement of the Black Sea Coast of the Caucasus," Soviet Geography 15, no. 3 (Mart 1974): 156-63; G.I. Filipson, "Vospominania," Russki arhiv 22, 1 (1884): 204, 211; i.V. Bentkovskiy, Zaseleniye Çernomoriya s 1792 po 1825 god. (Yekaterinodar: Tipografiya Kubanskago oblastnago pravleniya, 1880), 48, 69, 121; V.S. Bogoslavskiy, Pyatigorskiya is nimi smejnıya mineralnıye vodı (St. Petersburg: Tipografiya A.S. Suvorina, 1883), 7-8; A.V. Fadeyev, Rossiya $i$ Kavkaz pervoy treti XIX v. (Moskova İzdatelstvo Akademiy nauk SSSR, 1960), 67. Aynı şekilde Kuzeydoğu Kafkasya'da inşa edilen ilk kalelerdeki başlıca ölüm nedeni gortsıbaskınları değil hızlı ilerleyen hastalıklardı.

15 A.P. Pronşteyn, ed., Don $i$ stepnoye Predkavkaze XVIII-pervaya polovina XIX v. (Rostov-na-Don: Izd. Rostovskogo un., 1977), 60, 116.

${ }_{17}^{16}$ Fadeyev, Rossiya i Kavkaz, 35-41.

17 A. Tvalçrelidze, Stavropolskaya guberniya v statistiçeskom, geografiçeskom, istoriçeskom i selsko-hozyaystvennom otnoşeniyah (Stavropol: Tipografiya M.N. Koritskogo, 1897), 408.

18 Pyotrovskiy, Istoriya narodov Severnogo Kavkaza, 378-79; B.A. Kaloyev, "Zemledeliye v gorskih narodov Severnogo Kavkaza," Sovetskaya etnografiya 3 (Mayıs-Haziran 1973): 46. Kızlyar'daki buğday ticareti ile ilgili bkz. N. P. Gritsenko, Goroda Severovostoçnogo Kavkaza i proizvoditelnıye silı kraya (Rostov-na-Don: Izd. Rostovskogo universiteta, 1984), 109; T.Kh. Kumıkov and E. N. Kuşeva, ed., Kabardino-russkiye otnoşeniya v XVI-XVIII vv.: Dokumentı i materialı (Moskova: Izd. Akademiy nauk SSSR, 1957), 2: 215-18; Fadeyev, Rossiya i Kavkaz, 63-65; Aktı sobrannıye Kavkazskoy arheografiçeskoy komissiyey (Tiflis: Tipografiya Kantseliarii glavnonaçalstvuyuşçego grajdanskoy çastiyu na Kavkaze, 1870), 4: 37 [bundan sonra AKAK]. Kuban buğdayı ile ilgili, i. V. Rovinskiy, "Hozyaystvennoye opisaniye Astrahanskoy i Kavkazskoy gubernii," Trudı Stavropolskoy uçenoy arhivnoy komissii 2 (1910): bölüm 4, 58-60; "Vzglyad na Kavkazskuyu Liniyu," Severnıy arhiv 2, (Ocak 1822): 181.

${ }^{19}$ T.H. Kumıkov, Vovleçeniye Severnogo Kavkaza vo vserossiyski rınok $v$ XIX v. (Nalçik: Kabardino-Balkarskoye knijnoye izdatelstvo, 1962), 93-96; A.P. Berje, Çeçnya i çeçentsı (Tiflis: Kavkazski otdel Imperatorskago russkago geografiçeskago obşestva, 1859), 89; Baddeley, The Russian Conquest, XXXVI. 
${ }^{20}$ D. L. İvanov, "Vliyanie russkoy kolonizatsii na prirodu Stavropolskago kraya," Izvestiya Imperatorskago russkago geografiçeskago obşestva 22, no. 3 (1886): 225-54; Tvalçrelidze, Stavropolskaya guberniya, 62, 204.

21 Daniel H. Usner, Jr., Indians, Settlers, and Slaves in a Frontier Exchange Economy (Chapel Hill: University of North Carolina Press for the Institute of Early American History and Culture, 1992), 6.

${ }^{22}$ Bu Kumıkov'un kitabının başlığı olup (bkz. 19. dipnot) çoğu Sovyet ve Kafkas tarihçisi için bir analiz çerçevesi sunmaktadır.

23 O.V. Marggraf, Oçerk kustarnıh promıslov Severnogo Kavkaza s opisaniyem tehniki proizvodstva (Moskova: Tipografiya S.V. Guryanova, 1882), XIV-XI; G.N. Prozritelev, "Kavkazskoe orujiye," Trudı Stavropolskoy uçenoy arhivnoy komissii 7-9 (1915): bölüm 10, 1-5; "Statistiçeskiya izvestiya o Kavkazskoy oblasti i zemle voyska Çernomorskago," Jurnal Ministerstva Vnutrennıh Del 3, no. 5 (1830): 124-27.

24 Kumıkov, Vovleçeniye, 34-35; S.M. Bronevski, Noveyşiye geografiçeskiye $i$ istoriçeskiye izvestiya o Kavkaze (Moskova: Tipografiya S. Selivanovskogo, 1823), 2: 142-45.

${ }^{25}$ Naroçnitski, İstoriya narodov Severnogo Kavkaza, 80; A.I. Ahverdov, "Opisaniye Dagestana. 1804 g." İstoriya, geografiya i etnografiya Dagestana XVIII-XIX vv. Arhivnıye materialı, ed. M. O. Kosven ve H.M. Haşayev (Moskova: İzdatelstvo vostoçnoy literaturı, 1958), 213.

${ }^{26}$ P.G. Butkov, Materialı dlya novoy istorii Kavkaza s 1722 po 1803 god (St. Petersburg: Tipografiya Imperatorskoy akademiy nauk, 1869), 1: 163. Baskınlar hakkında: V.P. Lıstsov, Persidski pohod Petra I (Moskova: Izd. Moskovskogo universiteta, 1951), 98; "Materialı dlya statistiki Kizliarskago polka Terskago kazaçiago voyska," Voyennıy sbornik 12 (Aralık 1869): 213; F. i. Soymonov, Opisaniye Kaspiyskago morya (St. Petersburg: Imperatorskaya akademiya nauk, 1763), 102; ì. Popko, Terskiye kazaki s starodavnih vremen (St. Petersburg: Tipografiya Departmenta udelov, 1880), 253-54.

${ }^{27}$ George Miles, "To Hear an Old Voice: Rediscovering Native Americans in American History," Under an Open Sky, 55.

${ }^{28}$ Richard White, The Middle Ground: Indians, Empires, and Republics in the Great Lakes Region, 1650-1815 (New York: Cambridge University Press, 1991), X.

${ }^{29}$ V.B. Vinogradov ve T.S. Magomadova, "Gde stoyali sunjenskiye gorodki?" Voprosı istorii 7 (Haziran 1972): 205; V.A. Potto, Pamyatniki vremen utverjdeniya Russkago vladıçestva na Kavkaze (Tiflis: Tipografiya ştaba kavkazskogo voennogo okruga, 1906), 1: 55-57. 
${ }^{30}$ Kabuzan, Narodı Rossii, 227; N.İ. Voronov, ed, Sbornik statistiçeskih svedeniy o Kavkaze (Tiflis: Kavkazski otdel Imperatorskago russkago geografiçeskago obşçestva, 1869), kısım 2, bölüm B, 20-21.

${ }^{31}$ Alan W. Fisher, "Emigration of Muslims from the Russian Empire in the Years after the Crimean War" Jahrbücher für Geschichte Osteuropas 35 (1987): 356-71.

${ }^{32}$ AKAK (Tiflis, 1866), 1: 87. Gmelin esarette hayatını kaybetmiştir.

${ }^{33}$ AKAK, 1: 81, 85; Pyotrovski, İstoriya narodov Severnogo Kavkaza, 395; Kumıkov ve Kuşeva, Kabardino-russkiye otnoşeniya, 2: 269-73; Butkov, Materialı, 1: 317-19.

34 B.P. Berozov, Pereseleniye osetin s gor na ploskost (XVIII-XX vV.) (Orconikidze: İr, 1980), 56-59; B.A. Kaloyev, Osetinı, 2. baskı (Moskva: Nauka, 1971), 65.

35 Armyano-russkiye otnoşeniya v pervoy treti XVIII veka. Sbornik dokumentov (Erivan: Izdatelstvo Akademiy nauk Armyanskoy SSR, 1964), 37-41; Pyotrovski, İstoriya narodov Severnogo Kavkaza, 374, 463; N.G. Volkova, "O rasseleni armyan na Severnom Kavkaze do naçala XX veka," Istoriko-filologiçeski jurnal 3 (1966): 260; N.G. Volkova, Etniçeski sostav naseleniya Severnogo Kavkaza v XVIII-naçale XX v. (Moskva: Nauka, 1974), 200-1.

${ }^{36}$ N. Samarin, "Dorojınıya zametki," Severnaya pçela, no. 133 (1862): 550-51; Tvalçrelidze, Stavropolskaya guberniya, 277.

37 S.A. Kozlov, "Popolneniye volnıh kazaçih soobşçestva na Severnom Kavkaze v XVI-XVII vv.," Sovetskaya etnografiya 5 (1990): 47-56; V.B. Vinogradov ve T.S. Magomedov, "O meste pervonaçalnogo rasseleniya grebenskih kazakov," Sovetskaya etnografiya 3 (1972): 31-42; Vosstaniye I. Bolotnikova: Dokumentı i materialı (Moskova: Sotsekgiz, 1959), 84, 109-0; Krestyanskaya voyna pod predvoditelstvom Stepana Razina: Sbornik dokumentov (Moskva: İzdatelstvo Akademiy nauk SSSR, 1954), 1. 120, 14041; Butkov, Materialı, 1: 168; V. V. Mavrodin, ed., Krestyanskaya voyna $v$ Rossii v 1773-1775 godah: Vosstaniye Pugaçeva (Leningrad: İzdatelstvo Leningradskogo universiteta, 1966), 2: 76-77.

38 I.G. Gerber, "Opisaniye stran i narodov vdol zapadnogo berega Kaspiyskogo morya. 1728 g.," Istoriya, geografiya i etnografiya Dagestana, 60-63, 69. Gerber, bölgedeki Rus-Osmanlı sınırını kurmak üzere Dağıstan'a gönderilen bir komisyonun üyesiydi.

39 D.í. Romanovski, Kavkaz i Kavkazskaya voyna (St. Peterburg: Tipografiya tovarişçestva "Obşçestvennaya polza", 1860), Ek, iv; Pronştein, Don i stepnoye Predkavkazye, 54-55; L.B. Zasedateleva, Terskiye kazaki 
(Moskva: izdatelstvo Moskovskogo universiteta, 1974), 184-216; Bentkovski, Zaseleniye Çernomoriya, 19-20.

${ }^{40}$ Tvalçrelidze, Stavropolskaya guberniya, 269, 399.

41 Naroçnitski, istoriya narodov Severnogo Kavkaza, 59; A.V. Predteçenski, ed., "Krestyanskoye dvijeniye v Rossii v 1826-1849 gg." Sbornik dokumentov (Moskva: Sotsekgiz, 1961), 223-25; N. Varadinov, istoriya Ministerstva vnutrennih del (St. Peterburg: Tipografiya ministersvta vnutrennıhh del, 1861), 3: kitap 2, 292; F. Şçerbina, "Beglıye i krepostnıye v Çernomorii," Kiyevskaya starina 16 (Haziran 1883): 239, 244.

${ }^{42}$ Predteçenski, Krestyanskoye dvijeniye, 331-32, 672; Şçerbina, "Beglıye i krepostnıye," 240-45. Savaş bakanı köylü hareketlerinden o kadar telaşlanmışı ki serflerin Kafkasya'yaa kaçmasını engellemek amacıyla Astrahan'dan ve Saratov'dan Yekaterinoslav'a uzanan bir duvar inşa edilmesini teklif etti

${ }^{43}$ V.M. Kabuzan, İmeneniya $v$ razmeş̧̧eniy naseleniya Rossii $v$ XVIIIpervoy polovine XIX v. (Moskova: Nauka 1971), 167-70.

44 A.F. Fadeyev, Oçerki ekonomiçeskogo razvitiya stepnogo Predkavkazya $v$ doreformennıy period (Moskova: İdatelstvo Akademiy nauk SSSR, 1957), 168-69, 188-91; Naroçnitskiy, Istoriya narodov Severnogo Kavkaza, 76.

${ }^{45}$ Moritz Wagner, Travels in Persia, Georgia, and Koordistan (Londra: Hurst and Blacken, 1856), 1: 127.

${ }^{46}$ Potto, Kavkazskaya voyna, 2: bölüm 1, 86-87; Wagner, Travels in Persia, 1: 129.

${ }^{47}$ Butkov, Materialı, 1: 79; AKAK, 1: 84, 87-88.

${ }^{48}$ Dvijeniye gortsev severo-vostoçnogo Kavkaza v 20-50 gg. XIX veka. Sbornik dokumentov (Mahaçkale: Dagknigoizdat, 1959), 356-57, 486.

${ }^{49}$ AKAK, 12: 1398; Dvijeniye, 471, 498; Baddeley, The Russian Conquest, 397; Friedrich Wagner, Schamyl and Circassia, çev. Kenneth R.H. Mackenzie (Londra: G. Routledge and Co., 1854), 88; Baron August von Haxthausen, The Tribes of the Caucasus, çev. J.E. Taylor (Londra: Chapman and Hall, 1855), 98. Rus yazar Bestujev-Marlinski'nin aslında Şamil olduğuna, soyguncu Dağlı çetesine katıldığına, İran'a kaçtı̆̆ına ya da beş eşiyle birlikte dağlarda yaşadığına dair söylentiler vardı. Bkz. A.L. Zisserman, Dvadtsat pyat let na Kavkaze (1842-1867) (St. Petersburg: Tipografiya A.S. Suvorina, 1879), 1: 329; Lauren G. Leighton, Alexander Bestujev-Marlinsky (New York: Twayne Publishers, 1975), 35.

${ }^{50}$ Alexander Puşkin, A Journey to Arzrum, çev. Birgitta Ingermanson (Ann Arbor: Ardis, 1974), 30-31. Rus askeri kuvvetlerinin yerlileşmesini kanıtlayan başka bir gerçek de Kafkasya'nın en despot ve şovenist Rus 
“kahramanı" Yermolov'un üç Müslüman kadınla “evlenmesiydi." Bkz. A.P. Berje, "Aleksey Petroviç Yermolov i ego kebinnıye jenı na Kavkaze 18161827 gg.," Russkaya starina 15 (Eylül 1884): 523-28.

${ }^{51}$ AKAK, 1: 88; Mavrodin, Krestyanskaya voyna, 76.

52 Samarin, "Dorojnıya zametki," 550; Potto, Kavkazskaya voyna, 1: 7679; Potto, Pamyatniki, 1: 19-20. 